\title{
Suvremena hrvatska povijest i nevolje s revizionizmom
}

\author{
DAVOR MARIJAN \\ Hrvatski institut za povijest \\ Zagreb, Hrvatska \\ dmarijan66@gmail.com
}

\begin{abstract}
U Hrvatskoj se pojam povijesni revizionizam javio početkom XXI. stoljeća. Pojam revizionizam do tada je bio isključivo u sferi marksizma, što je u slučaju Hrvatske (i Jugoslavije) bila stvarnost od 1945. do 1990. godine. Pojam povijesni revizionizam uveo je Slavko Goldstein, osoba koja nije bila po vokaciji povjesničar, no taj je pojam od tada prisutan na lijevom krilu historiografije i hrvatskoga društva. U radu se objašnjavaju okolnosti kako je pojam ušao u uporabu i dovodi u pitanje smislenost njegova korištenja.

Ključne riječi: historiografija; revizionizam; Slavko Goldstein; Franjo Tuđman; Nezavisna Država Hrvatska; Socijalistička Republika Hrvatska; Republika Hrvatska
\end{abstract}

\section{Uvod}

Slom komunizma u Europi 1989. doima se primjerenom granicom moderne i suvremene povijesti. Za zemlje zapadne Europe možda, ali za zemlje u kojima su na vlasti bili komunisti stvari su ipak složenije. Ni Hrvatska nije iznimka. Ona je bila dio Socijalističke Federativne Republike Jugoslavije (SFRJ), iz koje se izdvojila tijekom rata 1991. - 1992., koji je okončan početkom 1998. mirnom reintegracijom hrvatskoga Podunavlja. Hrvatska nije dovršila prijelaz iz komunizma u višestranačje ili, kako to kažu politolozi, nije napravila tranziciju iz totalitarizma u demokraciju. Ostalo je društvo reducirano po nacionalnom ključu i neznatno prilagođenim svjetonazorskim obrascima koji su stvarani u desetljećima komunizma. Posljedica je, među ostalim, duboko ideološki podijeljeno društvo i dominantni obrasci totalitarne svijesti, gdje postoje samo kategorije „mi” i „oni”. Jedna od ključnih točki podjela jest Drugi svjetski rat, koji se proračunato i neprimjereno, ali sustavno banalizira na neodrživu relaciju ustaše - partizani, odnosno fašizam - antifašizam, čime se granica suvremene hrvatske povijesti može staviti i u 1941. godinu. Ni razdoblje između dva svjetska rata nije apsolvirano i ono također generira podjele. Jugoslavija je, očekivano, ostavila dubok trag koji se različito vrednuje, dobrim dijelom iz 
osobnih perspektiva. Utjecaj tih podjela ograničava rad profesionalne historiografije na suvremenoj povijesti zbog najmanje dva razloga - prozivanja za povijesni revizionizam i prevelikoga utjecaja javne povijesti, odnosno nestručnih pojedinaca i skupina u javnom prostoru.

O povijesti suvremene hrvatske historiografije posljednjih godina napisano je nekoliko knjiga koje se uglavnom odnose na razdoblje od 1945. do 1960., a dijelom su relevantne i za ovu problematiku. To su monografije Snježane Koren i Magdalene Najbar-Agičić. ${ }^{1}$ Monografija Branimira Jankovića bavi se historiografijom razdoblja kasnoga socijalizma. ${ }^{2}$ Njezin je veliki nedostatak što nije korišteno arhivsko gradivo Centralnoga komiteta Saveza komunista Hrvatske (CK SKH). To posebice dolazi do izražaja kada se usporedi pristup sličnim temama nekih povjesničara iz Srbije. ${ }^{3}$

Temama suvremene povijesti bave se najmanje tri generacije povjesničara, koje mi se nekako čini logičnim podijeliti na one koji su do 1990. bili u sustavu znanosti, potom drugu generaciju, koja je školovana u komunizmu, no profesionalno je djelovala od 1990., i na kraju treću generaciju, koja je radove počela objavljivati u XXI. stoljeću. Dio njih potpuno različito vrednuje razdoblja koja su prošli i kojima se bave: Drugi svjetski rat, komunizam i iskorak u višestranačje. U skladu s tim različito ocjenjuju radove svojih kolega. Generacijska podjela ne podrazumijeva identične ideološke i svjetonazorske poglede, istomišljenika ima u svim generacijama. Valja napomenuti da se prva generacija $\mathrm{u}$ potpunosti srela s utjecajem komunističke ideologije, a druga posredno, u procesu školovanja i življenju u komunističkom režimu.

U sklopu nastojanja da stvori „novoga čovjeka” povijest je imala važno mjesto u djelovanju Komunističke partije Jugoslavije (KPJ) i Saveza komunista Jugoslavije (SKJ), odnosno Partije. ${ }^{4}$ Ustaljena je tvrdnja da nijedna znanost u komunizmu nije bila u tolikoj mjeri u fokusu Partije kao historiografija. Referat Josipa Broza Tita na V. kongresu KPJ iz 1948. smatra se kanonskim tekstom kojim su postavljene interpretacijske smjernice koje su opstale na snazi do samoga kraja Jugoslavije i SKJ. ${ }^{5} \mathrm{Ne}$ isključujem mogućnost da je dijelom i sada na snazi u krajnje lijevim krugovima dijela društava zemalja nekadašnje Jugoslavije. ${ }^{6}$ Interes Partije vidljiv je i u postojanju posebnih tijela zaduženih za historiju od ranih 1950-ih u društveno-političkim organizacijama, kao i na lokalnim,

\footnotetext{
1 KOREN, Politika povijesti u Jugoslaviji (1945-1960); NAJBAR-AGIČIĆ, U skladu s marksizmom ili činjenicama?

2 JANKOVIĆ, Mijenjanje sebe same.

3 STANKOVIĆ, DIMIĆ, Istoriografija pod nadzorom.

4 Zbog moći kolikom je raspolagala, naziv Partija primjerenije nego ime Savez odražava stvarno stanje raspodjele moći u Jugoslaviji. Pod tim se, naravno, razumijeva onaj manji dio SKJ koji je držao sve poluge vlasti. GOATI, SKJ, kriza, demokratija, 8-9.

BROZ TITO, „Politički izvještaj”, 7-166. O značenju i posljedicama izvješća u: BANAC, „Rat prije rata”, 15-16; STANKOVIĆ, DIMIĆ, Istoriografija pod nadzorom, 291-297; NAJBARAGIC̈IĆ, U skladu s marksizmom ili činjenicama?, 403-405.

6 Primjerice, Hrvatsku predstavlja portal http://www.antifasisticki-vjesnik.org/hr/.
} 
kotarskim, kasnijim općinskim razinama. ${ }^{7}$ Na vrhu lanca bila je Komisija Predsjedništva CK SKH za historiju SKH kao jedno od njezinih stalnih radnih tijela. Primjerice, nakon 9. kongresa SKH Predsjedništvo Centralnoga komiteta imenovalo je 5. srpnja 1982. novu 23-članu Komisiju na čijem je čelu bio sveučilišni profesor, povjesničar Rene Lovrenčić, koji je u prethodnom partijskom sazivu bio i član Predsjedništva. U Komisiji su bili: Milutin Baltić, Anka Berus, Dušan Bilandžić, Jure Bilić, Jakov Blažević, Ljubo Boban, Ivan Božičević, Marijan Cvetković, Ljubo Drndić, Bosiljka Janjatović, Slavko Komar, Sibe Kvesić, Dušan Plećaš, Vojo Raičević, Hodimir Sirotković, Mihajlo Sobolevski, Zorica Stipetić, Petar Strčić, Radovan Trivunčić, Fabijan Trgo, Mate Ujević i Đuka Zatezalo. ${ }^{8}$ Bio je to spoj profesionalnih povjesničara i vrlo utjecajnih istaknutih revolucionara, čija je riječ imala veću težinu od riječi struke. Povjesničarima koji se bave suvremenom poviješću većina tih osoba nedvojbeno je poznata.

Kompleksnost suvremene povijesti, posebice spornih epizoda i osoba, ilustrira primjer enciklopedijske jedinice o Andriji Hebrangu potkraj 1985. godine. Redakcija za SKJ Enciklopedije Jugoslavije tražila je od Predsjedništva CK SKH da izradi natuknicu za Hebranga za četvrti svezak Enciklopedije Jugoslavije, o čemu je ostale članove 5. studenog obavijestio član Predsjedništva Stipe Šuvar. Natuknicu o Hebrangu napisao je Ivan Perić iz Splita. ${ }^{9}$ Predsjedništvo CK SKH zadužilo je na sjednici 19. studenog Anku Berus, Pavla Gregorića, Milutina Baltića, Marijana Cvetkovića i Nikolu Sekulića da „dadu svoje mišljenje” da „nakon toga Predsjedništvo CK SKH zauzme svoj stav”. ${ }^{10}$

Sredinom veljače 1985. održana je zajednička sjednica Komisije Predsjedništva CK SKH za historiju SKH i Komisije CK SKH za idejni i teorijski rad, na kojoj je dogovoren prijedlog „Akcionog programa unapređivanja proučavanja i nastave novije historije u Hrvatskoj". ${ }^{11}$ Kao podsjetnik za raspravu na sastanku obiju komisija bio je "pripremljen analitičko-dokumentarni materijal o nekim od karakterističnih primjera zloupotreba i falsificiranja povijesne istine". U materijalu su navedeni „brojni primjeri” zloporaba i „povijesnih falsifikata u kojima se na sve otvoreniji i grublji način, pod plaštem utvrđivanja 'naučne istine, vrši grubo prekrajanje i falsificiranje naše najnovije povijesti, posebno povijesti Saveza komunista i revolucije, i udara na same temelje i humanističke vrijednosti i dostignuća revolucije". Nabrojene su problematične teze: stvaranje i karakter Kraljevine Jugoslavije, Travanjskoga rata 1941. i zbivanja u Hrvatskoj;

7 NAJBAR-AGIČIĆ, U skladu s marksizmom ili činjenicama?, 417-419.

8 HR-HDA-1220-CK SKH, Pov-D-3346/6: Predsjedništvo CK SKH, Odluka o sastavu Komisije PCK SKH za historiju SKH, br. 02/P-2/53-1982 od 5. 7. 1982. Napomena: imena članova Komisije navedena su prema dokumentu.

9 HR-HDA-1220-CK SKH, Str. pov-4091: Predsjedništvo CKSKH, br. 03/11-Sl./85 od 5. 11. 1985.

${ }^{10}$ HR-HDA-1220-CK SKH, SP-D-4091: Skraćeni zapisnik sa 168. sjednice Predsjedništva CKSKH od 19. 11. 1985.

${ }^{11}$ HR-HDA-1220-CK SKH, SP-D-3961: Komisija PCKSKH za historiju SKH - Komisija CKSKH za idejni i teorijski rad, Akcioni program unapređivanja proučavanja i nastave novije historije u SRH (prijedlog), br. 05/4-1180/1-85 od 14. 3. 1985. 
revolucionarna uloga radničkoga pokreta i Partije u „dizanju ustanka”; slučaj Andrije Hebranga; broj žrtava okupatorsko-kvislinškoga terora; karakter 27. ožujka; uloga Mačeka i Hrvatske seljačke stranke (HSS); politika Kominterne prema prvoj Jugoslaviji itd. Zaključeno je da se „,napadi na ključne i prelomne događaje i ličnosti revolucije vrše s različitih ideoloških pozicija, od nacionalističkih i kleronacionalističkih do dogmatsko birokratskih i građansko liberalnih i da pravi cilj tih autora nije želja da se bolje i produbljenije marksistički valoriziraju pojedina još nedovoljno osvjetljena zbivanja, već pokušaj prekrajanja povijesti revolucije i blaćenje njenih najistaknutijih aktera iz prizemno antisocijalističkih pobuda”, te da argumentirano „znanstveno suprotstavljanje tim pojavama i raskrinkavanje pravih ciljeva tih zloupotreba, posebno od strane komunista historičara” nije dovoljno i „moralo bi biti znatno šire, argumentiranije i ofanzivnije". Napomenuto je da su pojedini povjesničari, kada su to pokušali, „nailazili na prepreku, od odbijanja pojedinih redakcija da objave njihove tekstove, do pokušaja da ih se politički ili znanstveno diskvalificira". ${ }^{12}$ Taj je trend bio poticaj da se ,intenzivira i odlučnije krene u organizirana istraživanja i marksističku obradu ključnih problema iz svih razdoblja naše povijesti, a posebno povijesti radničkog i komunističkog pokreta, Saveza komunista, revolucije i socijalističke izgradnje”. Smatrano je nužnim bolje organizirati, okupiti sve „stvaralačke potencijale, smišljeno i planski stvarati nove marksistički orijentirane kadrove, osigurati veća financijska sredstva itd." ${ }^{13} \mathrm{U}$ osam točaka predložen je intenzivni rad, istraživanje i marksistička obrada ključnih problema povijesti radničkoga pokreta uz angažiranje svih raspoloživih kadrova, posebice instituta i centara za povijest radničkoga pokreta, katedri za povijest, arhiva, muzeja i sl. Predloženo je da se u idućih 4-5 godina u suradnji sa znanstvenicima i povijesnim institucijama precizno odredi i popis tema koje traže prioritetno istraživanje. Za takva istraživanja bilo je nužno uz kadrove osigurati i odgovarajuća financijska sredstva. Rukovodstvo SKH trebalo je inicirati poboljšanje stanja u povijesnim institucijama, uključujući i širenje takve mreže „kako bi se osigurala ravnomjernija obrada i istraživanje povijesti radničkog pokreta, Partije i revolucije u svim dijelovima Hrvatske". Kao prijedlog za razmišljanje natuknuto je da se regionalni instituti i centri integriraju s Institutom za historiju radničkoga pokreta Hrvatske u osnovne organizacije udruženog rada Instituta. Za javnu prezentaciju trebalo je koristiti javne tribine u Zagrebu i većim središtima i najvažnija sredstva informiranja (radio, televizija, dnevni i tjedni tisak). Najavljen je razgovor s predstavnicima sredstava javnoga informiranja da bi se utjecalo na to da se ne daje prostor pisanjima neprihvatljivim Partiji, tj. onoj vrsti koju je smatrala neodgovornom i idejno-politički i znanstveno neprihvatljivom. ${ }^{14} \mathrm{Na}$ sjednici Predsjedništva CK SKH održanoj 3. travnja 1985. „Akcioni program” prihvaćen je uz manje dopune dane na sjednici. ${ }^{15}$

\footnotetext{
12 Isto.

13 Isto.

14 Isto.

${ }^{15}$ HR-HDA-1220-CK SKH, SP-D-3961: Skraćeni zapisnik sa 141. sjednice Predsjedništva CKSKH od 3. 4. 1985.
} 
Navedeni primjeri solidan su putokaz za razumijevanje načina na koji je funkcionirala ona vrsta odnosa prema bliskoj prošlosti koju neki autori zovu partijskom historiografijom. ${ }^{16}$ Ivo Goldstein predložio je 2002. da se „prevladavajući odnos prema povijesti” u doba socijalizma/komunizma definira „kao 'partijnost”'. Za njega je to fenomen koji „označava način mišljenja i u konačnici tekst koji je 'prožet' ili kome je 'nametnut' način mišljenja koji je bio dominantan u redovima Komunističke partije ili Saveza komunista. To, nadalje, znači da je vrhunski kriterij 'pozitivnosti' ili 'negativnosti' da se nešto objavi ili prezentira na određeni način odlučujući zapravo interes partije". ${ }^{17}$

Povjesničari koji su školovani ili su živjeli na Zapadu smatraju da je utjecaj Partije na historiografiju bio velik. Ivo Banac zaključio je 1993. u članku o raspadu jugoslavenske historiografije da će historiografije zemalja sljednica „biti nejednake u skladu, kakvoći i usmjerenju, ovisno o stupnju ideologizacije u svakoj od njih. Povjesničarski ceh imat će težak zadatak pri uklanjanju ne samo nasljeđa komunističkog komandiranja nego i posljedica postkomunističkih rascjepa". Banac smatra da je

„do raspada jugoslavenske historiografije došlo zbog kontinuiteta strančarske odanosti promjenljivim ideološkim stjegovima. On ne može odgovoriti na pitanje zašto su toliki promijenili svoja marksistička uvjerenja (ako su ona takva uopće bila) tako brzo (ako je to doista bilo brzo) da bi uveli (ili tek održavali) nove političke realnosti. Posljedice za historiografiju, ali i za obične ljudske živote, goleme su”. ${ }^{18}$

Povjesničar Jure Krišto također smatra da je utjecaj Partije bio velik i da se posebice u Hrvatskoj to jako negira. Krišto smatra da sredovječna i mlađa ,generacija sveučilišnih profesora, stasalih u atmosferi komunističke ideologijske stege, a najčešće su i sami njezini pristaše, najgrčevitiji su branitelji komunističkog naslijeđa u historiografiji, kao i u društvu općenito". ${ }^{19}$ Krištinu tvrdnju iz 2005. (tj. 2002.) povjesničar B. Janković nedavno je ocijenio kao neprimjereno generaliziranje. ${ }^{20}$ On kaže:

„Jedan od argumenata koji spremno prihvaća šira publika i čitatelji na društvenim mrežama jest da je sve ono što je pisano u socijalističkoj/komunističkoj Jugoslaviji bilo toliko ideologizirano da ne može više ništa znanstveno vrijediti." $^{21}$

Takvih mišljenja ima i ona su doista generaliziranje. Marksistički pristup ne znači lošu historiografiju ako se drži znanstveno-metodološkoga pristupa.

\footnotetext{
${ }^{16}$ NAJBAR-AGIČIĆ, U skladu s marksizmom ili činjenicama?, 375.

17 I. GOLDSTEIN, „Od partijnosti u doba socijalizma do revizionizma devedesetih”, 60.

18 BANAC, „Rat prije rata”, 32.

${ }^{19}$ KRIŠTO, „Ideologija/politika i historiografija”, 76-77.

${ }^{20}$ JANKOVIĆ, Mijenjanje sebe same, 23.

${ }^{21}$ JANKOVIĆ, „Javni status znanja o Jasenovcu ili kako je javna povijest porazila akademsku historiografiju".
} 
Doprinos historiografije do 1990. izvan političke povijesti ne može se ignorirati, posebice $u$ istraživanju gospodarskih prilika. ${ }^{22}$ Pitanje je i koliko su uopće povjesničari prakticirali marksistički pristup. Rene Lovrenčić, predsjednik Komisije Predsjedništva CK SKH za historiju, primijetio je 12. rujna 1983. na sjednici Predsjedništva Centralnoga komiteta „da je historiografija u nas pretežno nemarksistička, ali je u svakom slučaju dobrom djelu formalno rutinerski marksistička bez obzira na pojedine prodore i doprinose". ${ }^{23}$ Povjesničar Petar Korunić naveo je 1998. nekoliko parametara koje je nužno ispuniti da bi se odgovorilo na pitanje u kojoj je mjeri hrvatska historiografija bila prožeta marksizmom. ${ }^{24}$

Smatram da problem komunističkoga nasljeđa u historiografiji nije marksistički pristup nego obrazac totalitarne svijesti, etiketiranje neistomišljenika i pokušaji diskvalifikacije bez nastojanja da se argumentima ospori drugačije mišljenje. Svjež je primjer intervju povjesničara Hrvoja Klasića za Slobodnu Dalmaciju povodom knjige Stjepana Loze o četničkim planovima, ustašama i zločinima u prvim mjesecima Nezavisne Države Hrvatske (NDH). ${ }^{25}$ Klasić je spremno komentirao knjigu koju nije pročitao. ${ }^{26}$ Integralni odgovor S. Loze Slobodna Dalmacija odbila je tiskati, no može ga se pronaći na nekim internetskim portalima. ${ }^{27}$ Što god mislili o Lozinoj knjizi, vrijedi pročitati njegov odgovor jer pokazuje što se zbiva kada se komentira tema o kojoj se malo zna i knjiga koju se nije pročitalo.

Što je bila partijnost ili partijska historiografija u Hrvatskoj (i Jugoslaviji) bit će mnogo jasnije kada se odgovori na pitanje što je bila Partija. Je li Partija bila avangarda radničkoga pokreta, kako je sama tvrdila, odnosno, kako se može čuti nakon njezine propasti, da je vodila najveći modernizacijski proces u povijesti naroda i nacionalnih manjina koji su živjeli u Jugoslaviji? ${ }^{28}$ Ili je bila organizacija koja je pola stoljeća vodila državu kao svoj ratni plijen, a da se

${ }^{22}$ Primjerice, kada je u pitanju suvremena povijest, nezaobilazan je doprinos Mire Kolar Dimitrijević.

${ }^{23}$ HR-HDA-1220-CK SKH, Pov-D-3717: Magnetofonski zapisnik sa 64. sjednice Predsjedništva CKSKH, održane 12. 9. 1983.

24 KORUNIĆ, „Povijesna struka i kritika hrvatske historiografije danas”, 171-173.

25 Snježana ŠETKA, „Povjesničar Stjepan Lozo: U NDH su Srbi provodili genocid nad Hrvatima a onda su ustaše optužili za zločin nad njima”, Slobodna Dalmacija (Split), on-line izdanje, 4. 11. 2018., pristup ostvaren 5. 2. 2019., https://www.slobodnadalmacija.hr/novosti/hrvatska/ clanak/id/573398/povjesnicar-stjepan-lozo-u-ndh-su-srbi-provodili-genocid-nad-hrvatima-aonda-su-39strasne39-ustase-optuzili-za-zlocin-nad-njima.

26 Damir PILIĆ, „Poznati povjesničar žestoko odgovara splitskom kolegi Lozi: Svi studenti povijesti morali bi ga se sramiti! Apsolutna je laž da su Srbi nad Hrvatima u NDH nad Hrvatima počinili genocid", Slobodna Dalmacija, on-line izdanje, 11. 11. 2018., pristup ostvaren 5. 2. 2019., https://www.slobodnadalmacija.hr/novosti/hrvatska/clanak/id/574514/poznati-povjesnicarzestoko-odgovara-splitskom-kolegi-lozi-svi-studenti-povijesti-morali-bi-ga-se-sramiti-apsolutna-je-laz-da-su-srbi-u-ndh-pocinili-genocid-nad-hrvatima.

27 „Odgovor Stjepana Loze Hrvoju Klasiću i Damiru Piliću”.

28 VUČETIĆ, „O jednom jubileju ili kako se (ne) sećamo Jugoslavije”. 
u slučaju „modernizacije” može govoriti samo o pseudomodernizaciji? ${ }^{29}$ Utemeljen odgovor očito nije moguć prije sustavnoga istraživanja, što uključuje i pojam modernizacije.

Do raspada SFRJ i rata težište istraživačkoga rada bilo je na Drugom svjetskom ratu i radničkom pokretu u skladu s interesom Partije. U „civilnoj” sferi osjetljiv Drugi svjetski rat bio je zona instituta za historiju radničkog pokreta, posebice splitskoga, koji je u 1980-ima napravio najviše na tom planu, uglavnom monografskim obradama partizanskih postrojbi iz Dalmacije. U tom je pogledu imao veći učinak od Instituta za historiju radničkog pokreta Hrvatske u Zagrebu, središnje institucije za modernu povijest, pod kojom su se podrazumijevali Drugi svjetski rat, povijest KPJ i radnički pokret. U cjelini se do 1990. najviše postiglo $u$ istraživanju komunističke oporbe, tj. građanskih stranaka između dva rata i druge, poražene strane u Drugom svjetskom ratu. Bilo je mnogo lakše i lagodnije istraživati poraženu stranu iako je na tom polju bilo i najviše manipulacija. Što od toga može izdržati sud povijesti? Veliki dio članaka i dalje je posljednja istraživačka riječ jer se poslije o tim temama nije ništa radilo. No ključne su teme problematične, osobito interpretacija uloge KPJ i SKJ. Primjerice, povijest Komunističke partije Hrvatske od 1937. do 1945. svakako zaslužuje temeljito reviziono istraživanje.

Tvrdnje poput one povjesničara Ive Goldsteina da se o svemu moglo pisati, „ali na odgovarajući način - primjerice, knjiga o Hebrangu ili Bleiburg", ne smatram smislenima. Ne smatram smislenim uspoređivati stupanj istraživačke slobode, jednostranost i pristranost prije i nakon 1989. godine. ${ }^{30}$ Povjesničari koje navodi ne uklapaju se u takvu tvrdnju: Ljubo Boban, Fikreta Jelić-Butić i Bogdan Krizman uglavnom su pisali o problematici gubitničke strane i to je područje na kojem su doista napravljeni znatni pomaci. Ostali povjesničari koje Goldstein navodi: Mate Suić, Nada Klaić, Tomislav Raukar, Jaroslav Šidak i Mirjana Gross, bavili su se uglavnom problematikom do 1918., prije Jugoslavije i povijesti KPJ, pa ne spadaju u posebno osjetljiva područja. ${ }^{31}$ Svođenje partizansko-komunističke problematike na nekoliko tabu-tema neupućenima je vjerojatno atraktivno, no pokazuje upitno razumijevanje problematike Drugoga svjetskog rata i djelovanja KPJ u njemu..$^{32}$ Goldsteinova tvrdnja da se o Bleiburgu smjelo govoriti, ali na „vrlo specifičan način”, pri čemu je naveo

\footnotetext{
${ }^{29}$ Slično mišljenje dijeli i sociolog ROGIĆ, Tehnika i samostalnost.

${ }^{30}$ I. GOLDSTEIN, „Od partijnosti u doba socijalizma do revizionizma devedesetih”, 60-61.

${ }^{31}$ Isto.

32 Isto, 63-64. Pregovori partizana s Nijemcima u ožujku 1943. desetljećima su bili tabu-tema, no nisu izišli u jugoslavensku javnost, kako tvrdi Goldstein, nakon Titova govora u Jablanici 1978., kao što se nakon toga nisu pojavili „mnogi memoari i historiografski radovi o tim pregovorima (pisali su i Đilas, i Velebit i Popović)". Đilasovi memoari Revolucionari rat objavljeni su na engleskom jeziku 1977. i Tito nije imao izbora, pa je i on spomenuo pregovore pravdajući ih „na specifičan način” kao primjer priznavanja Ženevskih konvencija. Vladimir Velebit prešutio je pregovore u svojim sjećanjima iz 1982. godine. Ratne bilješke Koče Popovića objavljene su u Beogradu 1988., a godinu poslije i razgovori Aleksandra Nenadovića s njim kada je „čelični” stisak Partije malaksao. Nekoliko godina prije, 1985., objavljena je knjiga Martovski pregovori Miše Lekovića.
} 
knjigu Milana Baste, spada u kategoriju „vidim ono što želim vidjeti”. ${ }^{33}$ Goldstein pritom zanemaruje da je bio u doticaju s osobama koje su ponešto znale o tome, no golema većina čitatelja u tome nije mogla vidjeti priznanje zločina na „vrlo specifičan način”. O isticanju Dušana Bilandžića kao primjera širenja prostora slobode u historiografiji dalo bi se raspravljati. ${ }^{34} \mathrm{Njemu} \mathrm{kritičnost} \mathrm{nije}$ bila jača strana, a usto je imao vrlo jako političko zaleđe. Bio je i član Izvršnoga komiteta CK SKH i spadao u kategoriju samoga vrha komunističke elite.

Kada je nakon Titove smrti 1980. počelo otvaranje „tabu-tema”, na red za propitivanje došla je i suvremena povijest. Etapa onoga što će poslije biti nazvano revizionizmom počela je upravo dovođenjem u pitanje Titove uloge $\mathrm{u}$ ratu i poraću. Narodnooslobodilački rat i revoluciju dio znanstvenika i publicista iz Srbije interpretirao je kao građanski rat. Od 1981. do 1986. objavljeno je nekoliko knjiga koje su potpuno osporile konstrukciju stvaranu desetljećima. Najpoznatije od njih napisali su Kosta Čavoški, Vladimir Dedijer, Veselin Đuretić, Vojislav Koštunica i Velimir Terzić. Partijski povjesničari koji su ostali odani Partiji većinu tih knjiga negativno su ocijenili, a Đuretićeva je nakratko bila i zabranjena. ${ }^{35} \mathrm{U}$ kritičkom osvrtu na neke teze V. Terzića o Vladku Mačeku, HSS-u i kardinalu Alojziju Stepincu povjesničar Ljubo Boban napisao je: „Za znanost ti dijelovi Terzićeve knjige mogu poslužiti samo kao zastrašujući primjer što se sve i kako u ime znanosti, i pod okriljem znanosti, može proturati kao znanost." ${ }^{\text {36 }}$ Iz pravovjernoga partijskoga korpusa bio je povjesničar Branko Petranović, koji je četnike Dragoljuba Mihailovića okarakterizirao kao najvažniju antifašističku pojavu u srpskom građanstvu, iako nije osporio službenu ocjenu njihova djelovanja. ${ }^{37}$

Te su pojave suvremenici nazivali valom ili prolomom kritike koja se javljala u sklopu širega osporavanja dotadašnjih konstrukata socijalističke stvarnosti. ${ }^{38}$ „Prolom kritike” u povijesti nije nazivan revizionizmom, nego su korišteni drugi nazivi za diskvalifikaciju: ideološki šund, prekrajanje povijesti, poluistina, krivotvorenje povijesne istine i sl. Revizionizmom ih je tek 1993. uzgredno nazvao povjesničar I. Banac, samo bez ikakvih etiketiranja, u skladu sa zrelijim civilizacijskim krugom iz kojega je došao. ${ }^{39}$ Ovlašteni partijski tumač socijalističke stvarnosti u Hrvatskoj, D. Bilandžić u 1980-ima također nije koristio pojam revizionizam za takve pojave iako je sam pojam spomenuo

\footnotetext{
${ }^{33}$ I. GOLDSTEIN, „Od partijnosti u doba socijalizma do revizionizma devedesetih”, 64.

${ }^{34}$ Isto, 65.

${ }_{35}$ DEDIJER, Novi prilozi za biografiju Josipa Broza Tita 2; TERZIĆ, Slom Kraljevine Jugoslavije 1941; KOŠTUNICA, ČAVOŠKI, Stranački pluralizam ili monizam; ĐURETIĆ, Saveznici i jugoslovenska ratna drama; BANAC, „Rat prije rata”, 22-25; MARIJAN, Hrvatska 1989. - 1992., 58-61.

${ }^{36}$ BOBAN, Kontroverze iz povijesti Jugoslavije, knj. 1, 366.

${ }_{37}$ PETRANOVIĆ, Revolucija i kontrarevolucija u Jugoslaviji (1941-1945), I, 129.

${ }^{38}$ Detaljno u: NIKOLIĆ, Prošlost bez istorije.

39 BANAC, „Rat prije rata”, 22-23.
} 
niz puta, ali isključivo u smislu kako ga je shvaćala i koristila Partija. ${ }^{40}$ Bilandžić pojam revizionizam nije koristio ni 1999. u knjizi Hrvatska moderna povijest, nego je ostao vjeran vremenu i pojmovniku Partije iz svojih zrelih dana. ${ }^{41}$ On je samo dopunio i prilagodio knjigu koju je pisao veći dio svoje karijere i objavljivao ju s manjim izmjenama i različitim naslovima.

Težište (kritičkoga) preispitivanja, znatnim dijelom iz političkih pobuda, bila je povijest Partije. Partiji je taj trend bio neprihvatljiv, ona je bila životno zainteresirana da nadzire interpretacije povijesti radi manipulacija u sadašnjici i očuvanju stečenih privilegija, što je posebice bilo aktualno u posljednjim desetljećima SFRJ. Slijedila je reakcija koja je osobito jaka bila u Socijalističkoj Republici Hrvatskoj (SRH), gdje je član Predsjedništva CK SKH zadužen za ideološka pitanja Stipe Šuvar poduzeo konkretne mjere u pokušaju zaustavljanja trenda koji je dovodio u pitanje dogovorene istine. Premda je njegov najpoznatiji potez rezultirao materijalom poznatim kao Bijela knjiga, za ovu problematiku važnije je savjetovanje o historiografiji održano u Zagrebu u proljeće 1983. godine. Jedan od sudionika primijetio je da zbog načina organizacije skupa nije isključena mogućnost da će kolati „priče kako je Centralni komitet SK Hrvatske organizovao skup na kome se, bez polemike, vršio obračun s nekim autorima", pri čemu je konkretno naveo Velimira Terzića i Vjenceslava Cenčića. ${ }^{42}$ Rasprave sa skupa objavljene su 1984. u zborniku Historija i suvremenost. Idejne kontroverze. ${ }^{43}$ Zbornik je trajan podsjetnik na vremena dogovorenih i nadziranih istina u desetljeću koje neki recentni tumači nazivaju liberalnim jednostranačjem. ${ }^{44}$ Skup ilustrira što se tražilo od historičara vremena za koje je Partija bila izravno zainteresirana, iako valja istaknuti da ona u Hrvatskoj nije imala većih problema s povjesničarima jer su odstupanja od „kanona” na vrijeme sankcionirana, kao u slučaju Trpimira Macana 1971. i Ivana Jelića 1980. godine..$^{45}$ To nisu samo dva primjera koja se prenose na cjelokupnu historiografiju, kao što primjećuje B. Janković, nego pokazatelj da treba voditi računa o utjecaju cenzure i autocenzure na dio povjesničara koji su jako pazili da odabirom tema ne naprave pogrešan korak kao što ga je u Bosni i Hercegovini napravio povjesničar Rasim Hurem. Njegova knjiga iz 1972., inače prva ozbiljna monografija jugoslavenske historiografije o Drugom svjetskom ratu, pokazala je da ne treba biti previše agilan i da Partija ne tolerira iskorake na svoju štetu. ${ }^{46}$ Utemeljeni su i prigovori da hrvatska historiografija nije "dovoljno govorila o hrvatskoj naciji”, i to se ne može relativizirati tvrdnjama

\footnotetext{
40 BILANDŽIĆ, Historija Socijalističke Federativne Republike Jugoslavije, 544-545. O revizionizmu na str. 218, 274-276, 428.

${ }^{41}$ BILANDŽIĆ, Hrvatska moderna povijest, 707-708.

42 LEKOVIĆ, „O nekim slabostima historijske nauke”, 143.

${ }^{43}$ Historija i suvremenost. Idejne kontroverze.

${ }^{44}$ BILANDŽIĆ, Hrvatska moderna povijest, 707, 746; JOVIĆ, Rat i mit, 13, 80; Vlado VURUŠIĆ, „Nacionalisti ne dopuštaju Hrvatskoj da iziđe iz rata”, Globus (Zagreb), 15. 12. 2017., 20-25.

45 BANAC, „Rat prije rata”, 19; RADELIĆ, Hrvatska u Jugoslaviji 1945. - 1991., 553-554.

46 KAMBEROVIĆ, „Prva kvalitetna sinteza historije Bosne i Hercegovine za vrijeme Drugog svjetskog rata", 7-8.
} 
o potrebi „kritičnosti prema pisanju o povijesti vlastite nacije”. ${ }^{47}$ Jer kako objasniti da su Hrvatska i Bosna i Hercegovina jedine republike (u slučaju Hrvatske može se reći i nacija) koje u komunizmu nisu imale napisanu ili bar započetu nacionalnu povijest, iako ju je Institut za hrvatsku povijest Sveučilišta u Zagrebu najavljivao u 1970-ima? Doduše nacionalnu, državnu, nisu imali ni Muslimani iz Bosne i Hercegovine, no oni nisu imali ni nacionalnu državu, a povijest Bosne i Hercegovine obrađena je kroz povijest Srba u višetomnoj Istoriji srpskog naroda iz 1980-ih. Pregled hrvatske nacionalne povijesti dobrim se dijelom učio iz knjiga Ferde Šišića i Vjekoslava Klaića napisanih u AustroUgarskoj Monarhiji ili prvom desetljeću Kraljevine Srba, Hrvata i Slovenaca. Iznimka su monografije Nade Klaić o Hrvatima u srednjem vijeku i razdoblje 1860. - 1914., koje je obrađeno u knjizi Jaroslava Šidaka, Mirjane Gross, Igora Karamana i Dragovana Šepića iz 1968. godine. U svakom slučaju, učinak na polju „nacionalne povijesti” nije bio reprezentativan, posebice ako se usporedi s učinkom srpske historiografije.

U 1980-ima, kada je srpski nacionalizam doveo u pitanje Jugoslaviju po Ustavu iz 1974., krajnje je aktualno bilo pitanje ustaških zločina nad Srbima u NDH. Potrebe srbijanske dnevne politike istisnule su iz uporabe uobičajeni pojam masovni ustaški zločini i zamijenile ga ,jačim” i zvučnim pojmom genocid i pitanjem odgovornosti počinilaca genocida. Pojam genocid postao je općeraširen i korišten je bez kriterija i ograde. ${ }^{48}$ Taj je trend i sada čest. Središnje mjesto u manipulacijama imao je najveći ustaški logor Jasenovac. Manipulacijama žrtvama suprotstavio se tada najveći hrvatski stručnjak za suvremenu povijest Ljubo Boban. Vrlo je vjerojatno da je to radio na poticaj SKH. Isto se može pretpostaviti i za knjigu o stradanju hrvatskih komunista u logoru Kerestinec Ivana Jelića, što je aktualizirano knjigom o Josipu Kopiniču, rukovodiocu obavještajnoga punkta Kominterne u Zagrebu. ${ }^{49}$

\section{Devedesete - „olovne godine za hrvatsku Klio”}

U devedesete godine hrvatska je historiografija ušla bez velikih kadrovskih lomova, ali s velikim gubitkom za suvremenu povijest jer je tijekom rata, 1992. i 1994., ostala bez troje najistaknutijih istraživača: Fikrete Jelić-Butić, Ivana Jelića i Ljube Bobana.

Institucionalnih promjena $\mathrm{u}$ historiografiji je bilo, $\mathrm{u}$ skladu s političkim promjenama, kao i sa širim nastojanjem da Hrvatska „,iziđe iz genitiva” ${ }^{50}$ Povjesničarka Iskra Iveljić napisala je 2004. da je promptno „promijenjena mreža institucija, te je osim nužnog dodavanja pridjeva hrvatski u nazive muzeja, arhiva i sl. došlo do ukidanja regionalnih instituta za povijest radničkog pokreta

\footnotetext{
47 JANKOVIĆ, Mijenjanje sebe same, 23-24.

48 BOBAN, Kontroverze iz povijesti Jugoslavije, knj. 2, 324; BOUGAREL, „Od krivičnog zakona do Memoranduma", 7-23; MARIJAN, Hrvatska 1989. - 1992., 61-63.

49 JELIĆ, Tragedija u Kerestincu, 5-6, 36.

50 O „ulasku u genitiv” u: RADELIĆ, Hrvatska u Jugoslaviji 1945. - 1991., 124, 192.
} 
i Muzeja revolucije, preimenovanja Instituta za suvremenu povijest u Hrvatski institut za povijest i osnutka Hrvatskih studija u Zagrebu kao nacionalnog pandana Filozofskom fakultetu". ${ }^{51}$ Te su promjene prvenstveno odraz rješavanja nacionalnoga pitanja, koje je potkraj stoljeća bilo temeljno političko pitanje u Hrvatskoj, kao i u ostalim državama bivše Jugoslavije. U institucionalnom smislu najveća je promjena bilo preimenovanje Instituta za historiju radničkog pokreta najprije u Institut za suvremenu povijest, a potom u Hrvatski institut za povijest. Povjesničar Neven Budak napisao je 2004. da je Institutu namijenjen zadatak da podrži nacionalistički pristup povijesti i da je stoga bio financijski protežiran kao i Hrvatski studiji, koji su osnovani s istom svrhom. ${ }^{52}$ Institut je postupno preuzeo ulogu središnje povijesne nacionalne institucije, što je desetljećima bio Odsjek za povijest Filozofskoga fakulteta, koji je Hrvatska demokratska zajednica (HDZ) kao stranka na vlasti, prema Budakovu mišljenju, smatrala uporištem marksističkih i jugoslavenskih povjesničara. ${ }^{53}$ Ako Budak ima pravo, ipak je u Tuđmanovo vrijeme napravljen iskorak u odnosu na razdoblje do 1990. godine. Nisu poduzimani personalni zahvati prema odsjecima Filozofskoga fakulteta. Dugoročno je ipak u Tuđmanovo vrijeme otvoren slobodan prostor za različite pravce u historiografiji. Iznimno važna katedra za ekonomsku povijest na Filozofskom fakultetu je ukinuta, i to godinama nakon smrti F. Tuđmana i upravo na poticaj onih koji su se navodno zauzimali za pluralizam tema i pristupa istraživanjima drugih tema osim političke povijesti. Iskra Iveljić smatra da su „1990-e bile 'olovne godine' za hrvatsku Klio". ${ }^{54}$

„Ta situacija odrazila se i na stanje u historiografiji. S jedne strane, zato jer su i povjesničari samo subjektivni pojedinci, s druge strane i stoga što je historiografiji bio namijenjen zadatak da pokaže kako su hrvatska nacija i državnost čvrsto i duboko ukorijenjene u prošlosti, pa su povjesničari gotovo trebali postati demijurzima nove nacionalne samosvijesti i državnosti. Tako je historiografija i opet trebala biti politizirana i ideologizirana kao i u komunizmu. Taj utjecaj 'izvana' ne smije se podcijeniti jer je i sam tadašnji hrvatski predsjednik Franjo Tuđman imao ambicija izravno utjecati na hrvatsku historiografiju." ${ }^{55}$

\section{Dalje je ustvrdila da u}

„široj javnosti prevladavao je stav da se svatko može baviti poviješću jer povjesničari nisu pravi profesionalci poput primjerice liječnika, koje odlikuje specijalističko znanje i vještina nedostupna laiku. Prošlost je najednom postala dostupna svim vrstama amaterizma, o njoj su se pravorijeci davali u širokoj a ne stručnoj javnosti. Recepcija najboljih historiografskih radova bila je često slaba ali su zato novine bile pune izjava samoproglašenih ili traljavih povje-

\footnotetext{
51 Isto, 32.

52 BUDAK, „Post-socialist Historiography in Croatia since 1990”, 150. No to Budaku nije zasmetalo da poslije i sam predaje na Hrvatskim studijima.

${ }^{53}$ Isto, 150, 155.

54 IVELJIĆ, „Hrvatska historiografija o 19. stoljeću nakon raspada Jugoslavije”, 43.

55 Isto, 32.
} 
sničara nacionalističkog pa i šovinističkog usmjerenja a pojedini 'nepodobni' povjesničari otvoreno su napadani u javnosti".56

Stajalište da se svatko može baviti prošlošću nije izum Tuđmanova doba niti je ograničeno samo na njega. Poviješću Drugoga svjetskog rata i revolucije uglavnom su se bavili sudionici rata okupljeni oko Jugoslavenske narodne armije ili Saveza udruženja boraca narodnooslobodilačkog rata. Na spomenutom ideološkom savjetovanju 1983. Stipe Šuvar rekao je: „[...] naša novija historija tiče se nas svih i ne može biti zabran samo historičara. Povijest nije samo pitanje povjesničara. Uostalom, historiju svi učimo i ona nas sve uči; utoliko nitko nije u njoj apsolutna neznalica niti može apstinirati od vlastitog promišljanja i opredjeljivanja." ${ }^{57}$ Slavko Goldstein dobio je u XXI. stoljeću veći medijski prostor od bilo kojega profesionalnog povjesničara iako po „Vokaciji” nije povjesničar, premda ga tako predstavljaju neki medijski krugovi. ${ }^{58}$ Očito, to „da se svatko može baviti poviješću” nije ništa novo na hrvatskim prostorima. Pitanje javne recepcije dobrih (ili manje dobrih) historiografskih djela i danas je u sferi osobnih poznanstava i uređivačke politike medija. Tu je suštini problema mnogo bliže komentar I. Banca da smo „dopustili prije svega medijima da stvaraju svoje popise relevantnih povjesničara, među kojima ima mnoštvo klasika bez djela. Koga briga što redoviti profesor, specijalist za srednji vijek, misli o problemima dvadesetog stoljeća, ili specijalist za hladni rat o Oktobarskoj revoluciji, da ne spominjemo hrpu banalnosti što dnevno izgovore anonimni asistenti i sredovječni docenti?"59 Očito je i u ovom slučaju riječ o pojavi dugoga trajanja. Nedvojbeno je da pojedini radovi, primjerice $S$. i I. Goldsteina, Tvrtka Jakovine, H. Klasića, imaju solidnu medijsku recepciju, no pitanje je da li je to posljedica njihove kvalitete ili drugih, neznanstvenih pobuda. Iskra Iveljić svojim je poopćavanjem samo dala doprinos procesu detuđmanizacije kada je to bilo u modi. Budak je otišao u veću krajnost komentarom da će jednoga dana biti zanimljivo istražiti je li za hrvatsku historiografiju Tuđmanova smrt možda bila veća prekretnica nego zbivanja 1990. godine. ${ }^{60}$ Iz njihovih stajališta moglo bi se zaključiti da je 1990. uslijedila anomalija i da je smrću Franje Tuđmana počeo povratak na... valjda profesionalne standarde koji su, usprkos utjecaju Partije, postojali do tada. Do sada nije dan argument da je F. Tuđman utjecao na historiografiju kao što je to činjeno do 1990. godine. Nisam siguran da se neodržani govor koji je planiran za 1.

56 Isto.

57 ŠUVAR, „Historija revolucije tiče se nas svih”, 10.

58 Primjerice: Miljenko JERGOVIĆ, „Slavko Goldstein: Tito je bio vođa zavjere šutnje o Bleiburgu”, Nedjeljni Jutarnji (Zagreb), 11. 11. 2007., 14-15; Željko IVANJEK, „7 ljudi koji su ostali mladi”, Jutarnji list (Zagreb), 4. 8. 2012., 34, 55-56; Boris PAVELIĆ, „Slavko Goldstein: Tito nije bio diktator”, Novi list: Pogled (Rijeka), 30. 5. 2015., 5-7; Jelena LOVRIĆ, „Kao veliki patriot, Hasanbegović bi ostavkom učinio uslugu Hrvatskoj”, Jutarnji list, 28. 5. 2016., 58-59.

59 Stjepan MATKOVIĆ, „Intervju: Ivo Banac, Bosna je prostor radosti”, Preporodov Journal (Zagreb), jun/jul 2019., 27.

60 BUDAK, „Post-socialist Historiography in Croatia since 1990”, 150. 
kongres povjesničara potkraj 1999. može smatrati pritiskom na historiografiju. Bar je u odnosu na neka prethodna razdoblja bilo moguće izraziti protivljenje njegovu nastupu. ${ }^{61}$ Povjesničar Ivo Banac, koji je devedesetih bio vrlo kritičan prema Tuđmanu u osvrtu na knjigu I. Goldsteina Dvadeset godina samostalne Hrvatske, napisao je „da je Tuđmanov sustav ipak bio pluralan, pa prema tome mnogo bolji od komunističkog. On je također izborno verificiran. Stoga se na njegovim polazištima i mogao graditi 'noviji' sustav nakon 2000. godine, koji također (treba li napominjati?), nije bio savršen”." ${ }^{2}$

Nakon smrti F. Tuđmana i promjena na čelu Hrvatske 2000. počelo je prozivanje za povijesni revizionizam u devedesetim godinama. To je bio samo mali dio koraka natrag nove vladajuće garniture, koja je umjesto najavljivanih demokratskih promjena započela detuđmanizaciju. ${ }^{63}$ Središtem povijesnoga revizionizma u Hrvatskoj smatran je Hrvatski institut za povijest. ${ }^{64}$ Ivo Goldstein prozvao je 2001. Institut da je „proteklih deset godina bio glavna karika u tuđmaniziranju hrvatske historiografije i uspio joj je nanijeti velike štete. $U$ izdanju Instituta izašle su i takve knjige koje propagiraju revizionističke ideje o Drugom svjetskom ratu". ${ }^{65}$ Upravo je iz kruga obitelji Goldstein krenulo prozivanje za (povijesni) revizionizam u historiografiji. Povjesničar Ivo Goldstein objavio je u suautorstvu s ocem Slavkom 2001. knjigu Holokaust u Zagrebu, u kojoj je jedno poglavlje posvećeno revizionizmu u historiografiji. Prema uvodnom objašnjenju, to je poglavlje napisao Slavko Goldstein. ${ }^{6}$ Veći dijelovi toga poglavlja objavljeni su poslije više puta u obliku članaka i poglavlja u knjizi koje su po potrebi pojedinačno potpisivali i otac i sin, a u jednom slučaju suautor je i povjesničar mlađe generacije Goran Hutinec. ${ }^{67}$

Do smrti 2017. Slavko Goldstein bio je osoba s velikim utjecajem na, uvjetno rečeno, lijevom krilu hrvatskoga političkog spektra. Dio svoje nazočnosti na javnoj sceni S. Goldstein temeljio je na potpori nekadašnjega medijskoga

${ }^{61}$ Slavica LUKIĆ, „Dr. Franjo Tuđman sprema se održati veliku lekciju hrvatskoj historiografiji!”, Globus, 9. 7. 1999., 10-13; Aleksandar BUCZYNSKI, „Vjerujem da će listopadski I. kongres hrvatskih povjesničara dokazati bogatstvo hrvatske historiografije!", Globus, 30. 7. 1999., 39.

${ }^{62}$ Ivo BANAC, „Tuđmanov sustav ipak mnogo bolji od komunizma”, Večernji list: Obzor (Zagreb), 29. 1. 2011., 12-13.

${ }^{63}$ Detuđmanizacija je nesumnjivo najveća tema hrvatske povijesti s početka XXI. stoljeća. Definiram ju kao pokušaj vraćanja sustava vrijednosti i institucionalnoga okvira koji je postojao prije izbora u proljeće 1990., samo izvan jugoslavenskoga okvira. Ivo Goldstein napisao je 2000. da je tuđmanizam u „nekom od svojih značenja, sinonim za sustav izokrenutih vrijednosti”, a da je detuđmanizacija „simbol, i bit, i najbolji termin za nužne promjene kako bi Hrvatska postala normalna i prosperitetna država”. Ivo GOLDSTEIN, „Bez hitne detuđmanizacije Hrvatska uopće ne može postati normalna država", Globus, 20. 10. 2000., 33. Za Slavka Goldsteina detuđmanizacija je ustvari deustašizacija, s tim da je detuđmanizacija češći pojam. S. GOLDSTEIN, I. GOLDSTEIN, Jasenovac i Bleiburg nisu isto, 207.

${ }^{64}$ BUDAK, „Post-socialist Historiography in Croatia since 1990”, 155.

${ }^{65}$ „Dr. Ivo Goldstein: Institut za povijest je kompromitiran”, Jutarnji list, 11. 3. 2001., 5.

${ }^{66}$ I. GOLDSTEIN, Holokaust u Zagrebu, 596-618.

${ }^{67}$ I. GOLDSTEIN, „Od partijnosti u doba socijalizma do revizionizma devedesetih”; I. GOLDSTEIN, HUTINEC, „Neki aspekti revizionizma u hrvatskoj historiografiji”; S. GOLDSTEIN, I. GOLDSTEIN, Jasenovac i Bleiburg nisu isto. 
koncerna Europapress Holding. Slavka Goldsteina teško je svrstati, uglavnom ga se navodi kao nakladnika i publicista ${ }^{68}$ No u ovom slučaju bio je, da se izrazim riječima bivšega sustava, društveno-politički radnik koji je nastupao s pozicije povjesničara premda se, u najpovoljnijem slučaju, može nazvati političkim aktivistom koji je nastojao utjecati na identitetska pitanja hrvatskoga društva. On je 2001. ustvrdio da se revizionizam

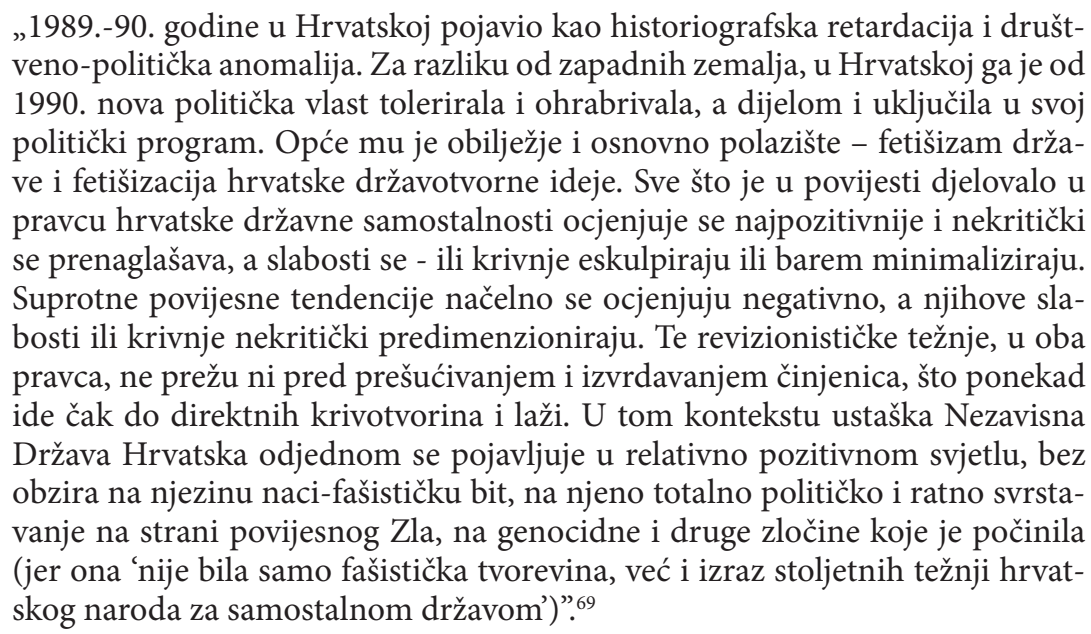

U tom dijelu teksta stavljena je napomena u kojoj piše „Često citirana rečenica iz govora Franje Tuđmana na I. saboru HDZ-a 24. veljače 1990. godine u Zagrebu”. 70 „Nasuprot tome”, nastavlja S. Goldstein, „slabosti i krivnje obiju jugoslavenskih država, a osobito zločini počinjeni u njihovo ime, apsolutiziraju se i generaliziraju do te mjere, da bi postali argumenti rigidnoj nacionalističkoj politici te po mogućnosti opravdanje ustaškim zločinima ili bar njihovoj relativizaciji." ${ }^{71}$

Slavko Goldstein smatra da postoje tri uzroka pojave revizionizma u Hrvatskoj. Prvo, to je posljedica 45 godina komunističkoga vladanja i njihova tendencioznoga pristupa problematici ustaštva i istovremenoga prešućivanja partizanskih i komunističkih ratnih i poratnih zločina. Drugo, zbog političkih ciljeva autora koji se bave historijskim revizionizmom, uglavnom da bi se ustaštvu dao kakav-takav legitimitet za sudjelovanje u izgradnji hrvatskoga društva u „okruženju dominirajuće evropske demokracije”. To je bila optužba protiv HDZ-a i dijela političke emigracije, koja, smatra Goldstein, nije raskinula s ustaštvom. Treće, revizionizam se dijelom javio kao reakcija na „bujanje srpskog nacionalizma i historiografskog revizionizma osamdesetih godina”.72

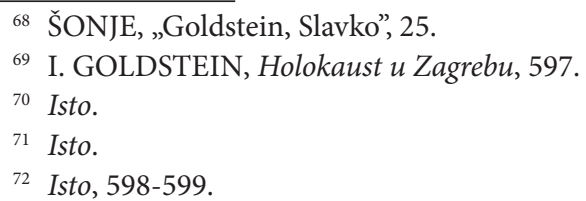


Potom je i Ivo Goldstein ustvrdio da je odnos „prema prošlosti tijekom devedesetih najbolje” definirati „kao 'revizionizam". ${ }^{73}$ Naveo je da su Tuđmanovu rečenicu sa I. sabora HDZ-a drugi počeli koristiti iako se Tuđman od nje ogradio „shvaćajući sve opasnosti koje iz nje proizlaze”. Usto je Tuđmanova ideja o „pomirenju svih Hrvata” omogućila „da se u javnosti toleriraju ekstremni nacionalizam i proustaški ispadi, pa je time i revizionistička historiografija dobila 'vjetar u leđa"'. Kao primjer revizionističke historiografije Goldstein je naveo knjigu Hrvoja Matkovića Povijest NDH, tvrdeći da je pisana „onako kako je odgovaralo tadašnjem državnom rukovodstvu”. ${ }^{74}$ Goldstein je Matkoviću zamjerio da nije taksativno naveo podatke o ustaškim žrtvama iz knjige F. JelićButić o ustašama, smatrajući da je upravo njezina knjiga bila podloga za jedno poglavlje, što znači da Goldstein smatra da su ti podaci neupitni. ${ }^{75}$ Govoreći o odnosu spram Jugoslavije, Goldstein je operirao s tvrdnjama da se ne može odrediti „korisnost” ili „štetnost” jer su to kategorijalni aparati politike. ${ }^{76} \mathrm{No}, \mathrm{u}$ koji kategorijalni aparat spada njegova tvrdnja o strani „povijesnog zla” u radu koji je 2007. potpisao s Goranom Hutincem? ${ }^{77}$ Staljinisti, predvodnici strane koja se u Hrvatskoj (ali i Jugoslaviji i Europi) od ljeta 1941. do ljeta 1945. borila protiv „povijesnog zla”, bili su od jeseni 1939. do ljeta 1941. saveznici „povijesnog zla", a potom su sa zapadnom demokracijom napravili neprirodni savez, od kojega nakon završetka rata nije ostalo ništa. Za razliku od porobljenih zemalja zapadne Europe, srednja Europa imala je nesreću da ih terora nacionalsocijalista riješi Crvena armija i da potom dobiju teror komunizma gotovo četiri puta dužega trajanja. Ista je stvar s Jugoslavijom, koju su komunisti uz veliku pomoć Crvene armije obnovili i zaveli režim o čijem karakteru nema suglasja. No ne bi bar trebalo biti sporno da je bio nedemokratski, i u lipnju 1945. i ljeto 1989. godine. Ne bi trebalo biti sporno ni da se komunistička Jugoslavija raspala prvom prilikom kada je stanovništvu dopušteno da slobodno bira na izborima. Stoga ne zvuče uvjerljivo riječi I. Goldsteina iz zbornika radova o reviziji prošlosti objavljenog 2007. u Sarajevu na temelju skupa održanog 2005., u kojem uz potporu G. Hutinca tvrdi da

„motivi autora koji se u Hrvatskoj bave historiografskim revizionizmom najčešće nisu znanstveno proučavanje bliže prošlosti, već određeni politički ciljevi. U najmanju ruku može se reći da tom poslu pristupaju s političkim predrasudama, na crti vladajuće politike iz razdoblja 1990-99. U pravilu se radi o desnim ili ekstremno desnim političkim orijentacijama kojima je jedno od osnovnih obilježja da se ne žele dolično suočiti sa zločinima koje su počinile ustaške vlasti za vrijeme NDH". ${ }^{78}$

${ }^{73}$ I. GOLDSTEIN, „Od partijnosti u doba socijalizma do revizionizma devedesetih”, 60. Iste rečenice ponovljene su i na str. 65-66.

${ }^{74}$ Isto, 67-68. Hrvoje Matković nazvao je tu tvrdnju besmislicom. MATKOVIĆ, „Razgovor s prof. dr. Hrvojem Matkovićem u povodu 80. godišnjice njegova života”, 1014.

75 I. GOLDSTEIN, „Od partijnosti u doba socijalizma do revizionizma devedesetih”, 67-68.

76 Isto, 68.

77 I. GOLDSTEIN, HUTINEC, „Neki aspekti revizionizma u hrvatskoj historiografiji”, 188-189.

78 Isto, 190. 


\section{Problem s određenjem pojma}

I tu dolazimo do problema kako uopće nazvati istraživanje koje kritički revalorizira prethodno razdoblje i pokušava dati odgovor utemeljen na primarnim izvorima i rezultatima dotadašnje historiografije. Je li uopće smisleno raspravljanje o tome, jer novija istraživanja revidiraju starije spoznaje i tu spora ne bi trebalo biti? Ili je za dio današnjih prozivača za revizionizam problem samo kada „revidiraju” drugi, a ne oni? Što se u drugoj polovini XX. stoljeća u Hrvatskoj, ali i Jugoslaviji, podrazumijevalo pod revizionizmom?

„Pojam 'revizionizam' u znanstvenoj se i političkoj publicistici ne upotrebljava jednoznačno. Dapače, nerijetko se ovim pojmom označavaju političke suprotne ideologije unutar radničkog pokreta. Ipak, pojam 'revizionizam' najčešće označava zahtjev da se 'ponovno pregleda' valjanost Marxovih i Engelsovih stajališta koji je zahtjev istaknut krajem prošlog i početkom ovog stoljeća. [...] Zahtjev za revizijom ideologije i teorije bio je istovremeno i zahtjev za revizijom političke strategije radničkih partija i promjenom političke taktike. On je značio priznavanje reformističkog prevladavanja kapitalističkog ustrojstva života",

napisao je 1981. politolog Ivan Prpić u predgovoru i popratnom tekstu zbornika tekstova o revizionizmu. Suština revizionizma bilo je odustajanje od diktature proletarijata i prihvaćanje pravila parlamentarne demokratske borbe. ${ }^{79}$ Slično objašnjenje, koje pojam revizionizam smatra dijelom povijesti marksizma i mišljenjem o odbacivanju diktature proletarijata i odabiru mirnog puta borbe, nalazi se i u Političkoj enciklopediji iz 1975. godine. ${ }^{80} \mathrm{U}$ udžbeniku povijesti za usmjereno obrazovanje iz 1988., koji su napisala šestorica poznatih povjesničara i politologa, postoji i rječnik kao dodatak. U njemu se revizionizam objašnjava kao „nastojanje da se izmijeni, preinači (revidira) marksizam u njegovom najbitnijem učenju (nužnost proleterske revolucije i uspostava diktature proletarijata)". ${ }^{11}$ Ta tri primjera prilično dobro ocrtavaju činjenicu da je revizionizam postojao u političkom pojmovniku socijalističke Jugoslavije, ali ne i u historiografiji.

Revizija doslovno znači ponovni pregled, provjera, i to bi trebao biti temelj znanosti jer u suprotnom robujemo stalnim i neupitnim istinama koje se tako pretvaraju u dogmu. U tom smislu nije loše krenuti od Zakona o reviziji iz prosinca 2005., u kojem se kaže:

„Revizija je postupak provjere i ocjene financijskih izvještaja i konsolidiranih financijskih izvještaja obveznika revizije te podataka i metoda koje se primjenjuju pri sastavljanju financijskih izvještaja (u daljnjem tekstu: financijski izvještaji), na temelju kojih se daje stručno i neovisno mišljenje o istinitosti i objektivnosti financijskog stanja, rezultata poslovanja i novčanih tokova." ${ }^{82}$

\footnotetext{
${ }^{79}$ PRPIĆ, „Napomena” i „Suvremenost Bernsteinova revizionizma”, VII-IX.

80 „Revizionizam”, 910.

${ }^{81}$ BILANDŽIĆ et al., Povijest 2, 316.

82 „Zakon o reviziji”, Narodne novine (Zagreb), 146 (2005), čl. 2.
} 
Može li se definicija prilagoditi historiografiji? Kao načelo, smatram da može, samo se umjesto „provjere i ocjene financijskih izvještaja” radi „provjera i ocjena" dosadašnjih interpretacija, izvora i literature. Što je tu sporno i čudno? Sporno je i čudno da povjesničar ne provjerava izvore ako su mu dostupni, nego se zadovoljava interpretacijom drugih povjesničara, često starom i nekoliko desetljeća. Revizija primarnih izvora vodi prema potvrdi postojeće interpretacije ili reinterpretaciji. Tijekom studiranja na Filozofskom fakultetu u Zagrebu na prijelazu iz komunizma u višestranačje i u vrijeme Domovinskoga rata samo sam se na studiju arheologije susreo s revizijom, točnije pojmom revizionoga istraživanja, premda je ono u toj znanosti jako teško jer je istraživački čin ujedno i stručna devastacija. ${ }^{83}$

No, što je povjesničar u Hrvatskoj koji radi reviziju? Revizor, revizionist ili samo znanstvenik koji se ne opterećuje političkim aktivistima i koji shvaća da bez revizije nema znanosti, ili je to iznimka samo u slučaju NDH? U članku o problemima istraživanja NDH povjesničar Marijan Maticka svojevremeno je ustvrdio da
„reinterpretacija povijesti odnosno povijesnih pojava i razdoblja svojstvena je samoj znanosti o povijesti, ona je dio povjesničareva postupka spoznaje proš- losti. 'Revizija povijesti', o kojoj se ponekad govori, a napose u okviru pokušaja valoriziranja historiografskih rezultata postignutih u razdoblju komunističke vlasti, uključujući i one o povijesti $\mathrm{NDH}$, u osnovi je postupak stran znanosti o povijesti. 'Revizija povijesti', a radi se zapravo o reviziji historiografije, u os- novi predstavlja osudu ili pomilovanje njezinih rezultata, ovisno o svrhovitosti i mogućnosti njihovog uklapanja u određeni ideološki sustav. Zato se pritom redovito teži jednoznačnosti, a odabrano rješenje smatra se potpunom i je- dinom 'pravom' povijesnom istinom. Revizija historiografskih znanja, a ona su uvijek samo privremena, dakle prvenstveno pripada području ideologije, a ne znanosti. Stoga mislim da profesionalni povjesničar/povjesničarka može govoriti isključivo o reinterpretaciji, a ne reviziji povijesti NDH". ${ }^{44}$

To je jedan kut gledanja i skloniji sam mišljenju povjesničarke Mirjane Gross. Ona se u knjizi Suvremena historiografija dotaknula i problematike revizije te rekla da „svaki iskaz zastaruje i zahtijeva reviziju, što sam i sama potvrdila ovom knjigom" ${ }^{85}$ U knjizi Historijska znanost iz 1976. reviziji nije dala prostor. Tek se u dopunjenom izdanju iste knjige dotaknula pojma u osvrtu na stanje u zapadnonjemačkoj historiografiji, gdje je spomenula djelomičnu reviziju historijskih interpretacija. ${ }^{86}$ Gross je komentar o reviziji u

\footnotetext{
${ }^{83}$ Najpoznatije reviziono istraživanje u arheologiji je ispravljanje datiranja sloja prapovijesne homerske Troje na nalazištu Hisarlik u Turskoj.

${ }^{84}$ MATICKA, „O istraživanju povijesti Nezavisne Države Hrvatske”, 254-255.

${ }^{85}$ GROSS, Suvremena historiografija, 381.

${ }^{86}$ GROSS, Historijska znanost, 356-357.
} 
Suvremenoj historiografiji dala kao zaključak i osvrt na mnoge povjesničare i povjesničarke koji

„uvjeravaju čitateljstvo da su njihovi fragmentarni i perspektivni rezultati istraživanja 'cijela istina', dakle odbijaju mogućnost alternativnih tumačenja. Umjesto toga, moralo bi biti prirodno i prihvatljivo da drugi povjesničari provjeravaju iskaze i iznose drugačija mišljenja, ako to ne čine neargumentirano i isključivo ideološko-političkim etiketiranjem". ${ }^{87}$

O temi revizije u povijesnoj znanosti pisala je i povjesničarka Zdenka Janeković Römer:

„Revizija' znači ponovno gledanje, preispitivanje, preinačivanje, ispravljanje. No ona može biti i više od toga - novi pogled koji se odvaja od etabliranoga gledišta i znači obnovu. Ponovno gledanje i reinterpretiranje, zauzimanje različitih, uvijek novih perspektiva, upravo je ono što čini epistemološki temelj povijesne znanosti. Revizija je njezino znanstveno oruđe, distinktivan način spoznavanja prošlosti. Historiografija nije spomenik, već živo tkivo koje u datom trenutku ima određeno značenje u znanstvenoj spoznaji i diskusiji, a već se u sljedećem spoznaje mijenjaju. Povijest je izrazito referencijalna disciplina, što znači da u svakom trenutku mora uzimati u obzir tradiciju interpretacija određenih problema, ali sa zadaćom da ih propituje i nudi nove odgovore, temeljem novih izvora i podataka ili reinterpretacijom i novim pogledima. Konsenzus oko nekih spoznaja igra ulogu u svakoj znanosti, pa tako i u povijesti, ali usprkos tome uvijek mora biti moguć iskorak, jer konsenzus nije motor promjena u povijesnoj spoznaji nego je to revizija." 88

Povjesničar mlađe generacije Branimir Janković, koji se uglavnom bavi problematikom povijesti historiografije, nedavno je primijetio da još

„jedan problem predstavlja javna zbrka s upotrebom termina revizionizam, koju je potrebno stručno i javno razjasniti. Naime dio povjesničara nerijetko u medijima ističe da je revizionizam uobičajeni dio stručne dinamike historiografije. I dok je revizija dosadašnjih spoznaja zaista uobičajena u historiografiji i općenito u znanosti, revizionizam međutim ima jasan širi cilj, najčešće prevrednovanja (u ovom slučaju NDH, oslobađajući je krivice za holokaust i druge zločine), a pojmom negacionizam trebalo bi označavati poricanja zločina". ${ }^{89}$

Jankovićevo tumačenje ne čini mi se smislenim i podsjeća me na kategoriju koja se pučki svodi na poslovicu „nije šija nego vrat”. U Hrvatskoj se očito nastavlja olako preuzimanje pojmova iz drugih političkih sustava, koji ne moraju imati isto značenje, a usto se nastavlja praksa etiketiranja i prozivanja onih

${ }^{87}$ GROSS, Suvremena historiografija, 381.

${ }^{88}$ JANEKOVIĆ RÖMER, „Problem revizije u povijesnoj znanosti”, 128.

${ }^{89}$ JANKOVIĆ, „Javni status znanja o Jasenovcu ili kako je javna povijest porazila akademsku historiografiju". 
koji misle drugačije. Pojmovnik revolucionarne ljevice u Hrvatskoj koji je bio na snazi do 1990. ostao je minimalno promijenjen i to je već veliki problem za društvene i humanističke znanosti, iako je u slučaju pojma „revizionizam” skrenuta pozornost na to da je riječ o jezičnom paradoksu. „Iako revizionizam jezički izražava svijest o potrebi kritičkog promišljanja i propitivanja naslijeđenih stajališta autoriteta i tako, nasuprot dogmatizmu, naglašava vrlinu ljudskog duha koja je pretpostavka teorijskog mišljenja, ovaj izraz u političkom rječniku znači odstupanje, zastranjenje, odnosno iskrivljivanje istinite teorije." ${ }^{\prime 0}$

Netom prevedena knjiga Domenica Losurda o historijskom revizionizmu bliža je određenju ovoga apsurdnog pojma. Bila je upitno smislena 1996., kada je izvorno objavljena, što se može reći i za prijevod u Hrvatskoj, posebice s pregovorom osobe koja ne razlikuje interpretacije od „povijesnih kretanja”. 91 Losurdo je bio marksist, član Komunističke partije Italije, angažirani djelatnik koji je pod krinkom znanstvenika proturao ideologiju koju je povijest porazila nekoliko godina prije. Za Losurda je povijesni revizionizam negiranje revolucionarne tradicije, tj. historijskoga ciklusa od 1789. do 1917. godine. ${ }^{92}$ Losurdo se drži pravovjerne marksističke definicije revizionizma i nakon propasti komunizma brani njegovu smislenost. Radi se o vrsti literature popularne među pripadnicima krajnje lijevoga političkog spektra koji se ne žele pomiriti s propašću komunizma, nestankom Jugoslavije i dijelu kojih je Hrvatska „okupirani teritorij". 93

\section{„Revizionisti”?}

U procesu detuđmanizacije nakon 2000. i historiografija je dala izvjestan obol, što je prije uzgred spomenuto. Prvi hrvatski predsjednik F. Tuđman godinama je prikazivan kao amoralna i pokvarena osoba tek svršenoga povijesnog razdoblja, simbolički i stoljeća. Slavko Goldstein, kao njegov politički protivnik, bio je važan zamašnjak u procesu detuđmanizacije s prozivanjem za povijesni revizionizam u kojem je Tuđmanu dao ključno mjesto. ${ }^{94} \mathrm{U}$ slučaju Tuđmana kao političara, a to je postao početkom 1989., može se govoriti o političkoj uporabi povijesti, u čemu nije bio ni prvi ni posljednji. U politici „pomirbe” Tuđman je preuzimao iz prošlosti sve što mu se uklapalo u političke planove. Pritom je mnogo više uzeo s „lijeve” strane, što njegovi kritičari s toga političkog pola zaboravljaju i ignoriraju. Tuđmanov govor na I. općem saboru HDZ-a sustavno se svodi na rečenicu o NDH i izvlači iz konteksta premda je bio znatno kompleksniji, pa se stječe dojam da ga mnogi, uključujući oba Goldsteina,

90 PRPIĆ, „Suvremenost Bernsteinova revizionizma”, XIII.

91 BOGDANIĆ, „Ideološki Trompe-l’oeil ili historijski revizionizam”, 5.

92 LOSURDO, Historijski revizionizam, 11.

93 Primjerice web-portali: http://www.antifasisticki-vjesnik.org/hr/; https://www.radnicki. org/; https://www.portalnovosti.com/. Za rubriku „okupirani teritorij”: https://radiogornjigrad. wordpress.com/category/otkacivanje-metamorfoze/okupirani-teritorij/.

${ }_{94}$ I. GOLDSTEIN, Holokaust u Zagrebu, 600. 
nikada nisu ni pročitali. Politolog Tihomir Cipek jedan je od rijetkih koji se korektno referira na taj govor. ${ }^{95}$ Tuđman je bio svjestan da antikomunisti čine većinu članova i pristaša HDZ-a i da ne vide ništa dobro u ljevičarskoj tradiciji. Stoga se trudio artikulirati ju u razumljivo i prihvatljivo tumačenje, ali i još jednom amnestirati i sebe i predstaviti prihvatljivijom prijašnju vlastitu pripadnost toj ideji. Objasnio je da pozivanje na avnojska i zavnohovska načela nije zbog političko-taktičkih pobuda, „nego zbog najdubljih povijesnih i međunarodnopravnih razloga", te da to ne znači ustavobraniteljska stajališta prema avnojskom poretku, nego polazišta da se nadograde i nadiđu, „pače i izlaze iz njegova vrijednosnog uporišta". Ono za što se Tuđman uhvatio bila su načela pune ravnopravnosti svih naroda, „a također prava svakoga, pa dakako i hrvatskog naroda, na samoodređenje do odcjepljenja”. Drugi razlog, koji je imao povijesnu i međunarodnu dimenziju, „koja je od ne manjeg značenja od nezastarivosti i neotuđivosti prava naroda na samoodređenje", jest to što se od Zemaljskoga antifašističkog vijeća narodnog oslobođenja Hrvatske „utemeljenom Federalnom Državom Hrvatskom - hrvatski narod na koncu drugog svjetskog rata našao na strani pobjedničkih demokratskih sila.". Topao-hladan odnos vidi se iz ocjene da je "hrvatski narod skupo stajalo uspostavljanje Titove jugoslavenske federacije”, ali i „da bi bez SR Hrvatske njegova sudbina bila neusporedivo teža. Da nije bio i na strani pobjednika, hrvatski narod, nakon propasti NDH s osovinskim silama, ne bi mogao izbjeći plan četničkog genocida, posljedice kojega su mogle biti katastrofalne".97 Tuđman nije zaboravio ni teritorijalno proširenje Hrvatske na zapadu. Time je zaokružena „obrana” teritorija koje su odredila komunistička antifašistička vijeća, jer bez SRH „kao nacionalne države hrvatskog naroda - bez obzira koliko s njome iz mnogih razloga bili nezadovoljni - pružalo je i dalje polazne osnove za opstojnost i dalje napore za oživotvorenje pune državne suverenosti hrvatskog naroda". ${ }^{98} \mathrm{U}$ kontekstu navedenog afirmativnije spominjanje NDH nije se moglo izbjeći. Ustvrdio je da „NDH nije bila samo puka 'kvislinška' tvorba i 'fašistički' zločin već i izraz kako povijesnih težnji hrvatskog naroda za svojom samostalnom državom, tako i spoznaja međunarodnih čimbenika, a u ovom slučaju vlade Hitlerove Njemačke, koja je na ruševinama versailleskoga krojila Novi europski poredak, tih težnji Hrvatske i njenih geografskih granica. Prema tome, NDH nije predstavljala samo puki hir osovinskih sila već je bila posljedak posve određenih povijesnih čimbenika". ${ }^{99}$ Može li se ta rečenica smatrati potporom NDH? Smatram da ne. ${ }^{100}$ Tuđman je uzimao iz prošlosti što mu je odgovaralo, pa je u tom smislu tekst I. Goldsteina „Upotreba povijesti” iz 1993. mnogo bliže suštini problematike nego posttuđmanovsko optuživanje

\footnotetext{
${ }^{95}$ CIPEK, „Politike povijesti u Republici Hrvatskoj”, 19.

${ }^{96}$ Odluke I. općeg sabora HDZ, 11-12.

97 Isto, 12-13.

${ }^{98}$ Isto. Dio odlomka preuzet je iz: MARIJAN, Hrvatska 1989. - 1992., 164-165.

99 Odluke I. općeg sabora HDZ, 9-10.

${ }^{100}$ Slično misli i CIPEK, „Politike povijesti u Republici Hrvatskoj”, 20.
} 
za revizionizam njegova oca nekoliko godina poslije. ${ }^{101}$ Isto se može reći i za članak I. Goldsteina iz 1996. o antifašizmu, kada je imao osjetno uravnoteženiji pristup od onoga s početka XXI. stoljeća. ${ }^{102}$

Rad Nikice Barića o antifašističkoj borbi u političkoj interpretaciji predsjednika Tuđmana potvrđuje da je on iz komunističkoga razdoblja uzimao ono što je smatrao korisnim. ${ }^{103}$ Tuđman je znatno pridonio, ako nije bio i odlučujući, u postavljanju temelja širokoj uporabi pojma antifašizam, koji je uz ljevičarsku tradiciju otežao, pa i onemogućio suočavanje s komunističkim zločinima, što njegovi kritičari slijeva ne smatraju problemom. Prema tome, Tuđmanov „revizionizam” osjetno je kompleksniji no što ga prikazuje obitelj Goldstein.

Slavko Goldstein je 2001. konkretno prozvao nekoliko osoba, od kojih je relevantan Jure Krišto, a veliku medijsku težinu, nerazmjernu značenju njegova znanstvenoga rada, ima i Josip Jurčević. Jure Krišto odgovorio je na prozivanje za revizionizam najprije u Glasu Koncila, a potom u Časopisu za suvremenu povijest. Prigovorio je Goldsteinima da se „postavljaju na samoizabrano visoko postolje moralne pravednosti te s njega dijele veće ili manje packe hrvatskim 'revizionistima', pritom im upućujući primjedbe koje se nerijetko i ne slažu s onim što uistinu zastupaju u interpretaciji novije hrvatske povijesti”. Prigovorio im je i da su prešutjeli ulogu Alojzija Stepinca u preseljenju doma staraca Saveza jevrejskih opština Jugoslavije na njegovo imanje u Brezovici i u njegovu održanju do kraja rata, uz objašnjenje da je to „bilo 'sukladno tada vladajućoj politici”'. Za Krištu je to dokaz da su

„Goldsteini odavno bili na poslu historijskog revizionizma, slušajući, osluškujući ili pak određujući što 'vladajuća politika' nalaže da se piše o povijesti. Kako se zove ispravljanje takvog revizionizma? Možda revizionizam revizionizma. U svakom slučaju to je naznaka da je deideologizirana i depolitizirana historiografija naša nasušna potreba". ${ }^{104}$

O potrebi deideologizirane i depolitizirane historiografije bilo je govora na znanstvenom skupu o hrvatskoj historiografiji u XX. stoljeću koji je u organizaciji Instituta Ivo Pilar održan 2002., a radovi s njega objavljeni su 2005. godine. Na njemu je J. Krišto primijetio da se svi pokušaji propitivanja i otklanjanja komunističkoga nasljeđa u historiografiji proglašavaju historijskim revizionizmom. ${ }^{105}$

\footnotetext{
${ }^{101}$ I. GOLDSTEIN, „Upotreba povijesti”, 52-61. Članak je uz „naknadne autorove stilističke korekture” prenesen u knjizi: S. GOLDSTEIN, I. GOLDSTEIN, Jasenovac i Bleiburg nisu isto, 281-304.

${ }^{102}$ I. GOLDSTEIN, „O antifašizmu jučer, danas i sutra”, 286-287.

${ }^{103}$ BARIĆ, „Antifašistička borba u Drugom svjetskom ratu”, 211-217. Također: BARIĆ, „Prvi hrvatski predsjednik dr. Franjo Tuđman o jugoslavenskom predsjedniku Josipu Brozu Titu”.

${ }^{104}$ KRIŠTO, „Još jedanput o knjizi Holokaust u Zagrebu”, 971.

${ }^{105}$ KRIŠTO, „Ideologija/politika i historiografija”, 77.
} 
Prozivanja za povijesni revizionizam razmjerno su učestala posljednjih nekoliko godina. Za revizionizam prozivaju političari, javni djelatnici, intelektualci i profesionalni povjesničari. Većina njih ima upitne kvalifikacije za ovu temu, a problem je kada prozivke dolaze od profesionalnih povjesničara koji, uz nekoliko iznimaka, takve tvrdnje uglavnom plasiraju preko raznih medija umjesto da jasno i utemeljeno izlože problem na jedinom relevantnom mjestu - u znanstvenim publikacijama. ${ }^{106}$ Bit će zanimljivo ustanoviti je li pojam povijesnoga revizionizma u dijelu susjednih država preuzet po uzoru na Hrvatsku.

U novije vrijeme najkonkretnija u prozivanju za povijesni revizionizam bila je politologinja Mirjana Kasapović, koja je 2018. u sklopu članka o genocidu u NDH izdvojila stariju revizionističku struju, u koju je uvrstila Josipa Jurčevića, Juru Krištu, Josipa Pečarića, Ljubicu Štefan i Petra Vučića iz 2001. godine. U novije revizioniste uvrstila je Blanku Matković, Vladimira Horvata, Mladena Ivezića, Vladimira Mrkocija, Stipu Pilića i Igora Vukića. ${ }^{107}$ Neki od spomenutih uopće nisu povjesničari. Rad M. Kasapović možda je i najkonkretniji članak u nabrajanju „revizionista”. No, napisala ga je autorica koja nema nikakvih referenci u ovoj problematici, osim ako ne dijeli mišljenje kolege Daga Strpića o politolozima koji su kvalificirani za gotovo sve probleme ovoga svijeta, što je inače pristup koji je i sama kritizirala. ${ }^{108}$

Očito je problematiziranje ustaških zločina u NDH srž „povijesnoga revizionizma”, u čemu posebno mjesto ima logor Jasenovac, koji je desetljećima bio neupitan simbol karaktera ustaškoga režima i jedno od najvećih stratišta u

\footnotetext{
106 Primjerice, povjesničari Hrvoje Klasić i Tvrtko Jakovina: Boris PAVELIĆ, „Povjesničar Hrvoje Klasić vlast smatra licemjernom: Većinski narod i vlast moraju spriječiti ustaštvo”, Novi list, on-line izdanje, 19. 4. 2016., pristup ostvaren 29. 5. 2019., http://www.novilist.hr/Vijesti/Hrvatska/Povjesnicar-Hrvoje-Klasic-vlast-smatra-licemjernom-Vecinski-narod-i-vlast-moraju-sprijeciti-ustastvo; „KLASIĆ: u Hrvatskoj i Srbiji na djelu tipičan revizionizam”; Vlado VURUŚĆ, „Nova knjiga povjesničara Hrvoja Klasića: Povijest nije samoposluga pa da se bira ono što je na aukciji", Jutarnji list, on-line izdanje, 20. 4. 2019., pristup ostvaren 29. 5. 2019., https://www. jutarnji.hr/kultura/knjizevnost/nova-knjiga-povjesnicara-hrvoja-klasica-povijest-nije-samoposluga-pa-da-se-bira-ono-sto-je-na-aukciji/8764334/; KLASIĆ, „Tri najveće revizionističke laži o Jasenovcu”; Tihomir PONOŠ, „Jakovina: Predsjedničine teze klasični revizionizam, a tajni posjet Jasenovcu - skandalozan", Novi list, on-line izdanje, 24. 4. 2015., posjet ostvaren 14. 6. 2019., http://www.novilist.hr/Vijesti/Hrvatska/Jakovina-Predsjednicine-teze-klasicni-revizionizam-a-tajni-posjet-Jasenovcu-skandalozan/; Denis ROMAC, „Jakovina o revizionizmu: Jedino se Hrvati pokušavaju iz pobjednika pretvoriti u poražene”, Novi list, on-line izdanje, 6. 6. 2017., pristup ostvaren 29. 5. 2019., http://novilist.hr/Vijesti/Hrvatska/JAKOVINA-O-REVIZIONIZMU-Jedino-se-Hrvati-pokusavaju-iz-pobjednika-pretvoriti-u-porazene; Tvrtko JAKOVINA, „Žrtvovanje prosinačkih žrtava na oltaru revizionizma: Zašto su one iz 1918. postale ideološki podobne, a one iz 1943. nepodobne i gurnute u zaborav", Globus, on-line izdanje, 29. 12. 2018., pristup ostvaren 29. 5. 2019., https://www.jutarnji.hr/globus/Globus-komentari/zrtvovanje-prosinackih-zrtava-na-oltaru-revizionizma-zasto-su-one-iz-1918-postale-ideoloskipodobne-a-one-iz-1943-nepodobne-i-gurnute-u-zaborav/8227295/; Dragan GROZDANIĆ, „Tvrtko Jakovina: bazen mržnje teško će se iscrpsti”, Novosti (Zagreb), on-line izdanje, 16. 10. 2018., pristup ostvaren 29. 5. 2019., https://www.portalnovosti.com/tvrtko-jakovina-bazenmrznje-tesko-ce-se-iscrpiti.

107 KASAPOVIĆ, „Genocid u NDH”, 8.

${ }^{108}$ KASAPOVIĆ, „Dvojac bez kormilara”, 145-146.
} 
Drugom svjetskom ratu, za koje se desetljećima tvrdilo da se točan broj ubijenih ne može odrediti, ali da broj ubijenih „žrtava premašuje 700.000 ”. ${ }^{109}$ S obzirom na broj stanovnika NDH i broj žrtava, Jasenovac bi na nekoj imaginarnoj rang-listi uvjerljivo odnio prvo mjesto najstrašnijega mjesta u Drugom svjetskom ratu. Potkraj 1980-ih brojka je osporena, u čemu je važnu ulogu odigrala knjiga Bogoljuba Kočovića iz 1985., koja je pokazala kako je uopće nastala brojka od 1.700.000 poginulih Jugoslavena u Drugom svjetskom ratu. ${ }^{110}$ Prema najnovijim podacima Javne ustanove Spomen-područje Jasenovac, u logoru je stradalo najmanje 83.145 žrtava. ${ }^{111}$ Brojka od oko 83.000 stradalih procjena je Vladimira Žerjavića, ekonomista koji je navodno, neovisno o Kočoviću, došao do sličnih procjena demografskih gubitaka. Iako je Kočović jasno govorio da nije dao procjenu žrtava u Jasenovcu, Žerjavić mu je pripisao brojku od oko 70.000 žrtava. ${ }^{112}$ U Srbiji i Republici Srpskoj te se brojke, kao premalene, uglavnom ne prihvaćaju i u optjecaju su one iz komunističkoga razdoblja. ${ }^{113}$

S obzirom na to da je u Hrvatskoj brojka žrtava Jasenovca umanjena minimalno osam puta, što je jedinstven slučaj u Europi, osnovano je pitanje kako to nazvati, kolektivnim revizionizmom ili krajem jedne polustoljetne manipulacije? Treba li se zapitati koliko je smisleno koristiti primjere revizionizma i negacionizma holokausta sa Zapada za obračune s onima koji ne misle drugačije u sustavu koji je bio potpuno drugačiji od onoga na Zapadu? Slavko Goldstein u tome nije vidio ništa sporno. On je 2001. ustvrdio da je u posljednjem desetljeću XX. stoljeća u politici, historiografiji, publicistici, medijima, školskim udžbenicima i „općenito u javnom životu” bilo „snažno nazočno nastojanje da se negiraju ili bar ublaže i zataškaju neke nesporne činjenice o ustaškoj NDH i o vremenu Drugoga svjetskoga rata” te da se radi o „specifičnoj hrvatskoj varijanti revizionizma, kvazihistorijskoj tendenciji koja se najprije sedamdesetih godina pojavila u Njemačkoj i Francuskoj, a zatim u SAD i u Velikoj Britaniji. Revizionisti u tim zemljama na razne su načine negirali ili minimalizirali nacističke zločine u Drugom svjetskom ratu, posebice one počinjene nad Židovima". ${ }^{114}$ Mlađi Goldstein ponadao se 2005. da će revizionistička historiografija biti marginalizirana u „slobodnoj diskusiji” ili bi u najtežim slučajevima trebala „doživjeti sudbinu sličnu onoj u liberalnodemokratskim zemljama: Robert Faurisson i David Irving tvrdili su da su plinske komore u nacističkim logorima smrti izmišljotina. Prvome je zabranjeno predavati na svim francuskim sveučilištima, a drugi je sudskom odlukom prisiljen platiti golemu odštetu koja ga je bacila na prosjački štap". ${ }^{115}$ Irving je optužen da

\footnotetext{
109 „Jasenovac”, 467.

${ }^{110}$ KOČOVIĆ, Žrtve Drugog svetskog rata u Jugoslaviji.

111 „Poimenični popis žrtava KCL Jasenovac”.

${ }^{112}$ KOČOVIĆ, Žrtve Drugog svetskog rata u Jugoslaviji, XVI i XVIII; ŽERJAVIĆ, Opsesije i megalomanije oko Jasenovca i Bleiburga, 72, 76.

${ }^{113}$ Deklaracija o genocidu Nezavisne Države Hrvatske nad Srbima, Jevrejima i Romima.

${ }^{114}$ I. GOLDSTEIN, Holokaust u Zagrebu, 596.

115 I. GOLDSTEIN, „Od partijnosti u doba socijalizma do revizionizma devedesetih”, 70.
} 
manipulira povijesnom građom i uskraćen mu je status povjesničara. ${ }^{116}$ Prema Goldsteinu, to bi trebao biti primjer kako postupati s revizionistima, i to $\mathrm{u}$ zemlji u kojoj je komunistički režim gotovo pola stoljeća manipulirao žrtvama ustaškoga režima s osnovnom intencijom višestrukoga uvećanja. Jasenovac je kruna tih manipulacija i vrh brijega prijepora koji tište hrvatsko društvo. Kao najizraženiji aspekt $\mathrm{NDH}$, nužan je radikalima s oba ideološka pola, jednima da, kako tvrde, spriječe povijesni revizionizam i onemoguće rehabilitaciju $\mathrm{NDH}$, a drugima da dokažu da je NDH bila posve drugačija od onoga što se tvrdilo u komunističkoj Jugoslaviji i što danas brani samo dio povjesničara s navodnoga lijevo-liberalnog spektra.

S obzirom na to da je brojka žrtava u Jasenovcu osjetno smanjena, moglo se očekivati da se i „dokazi” korišteni da potkrijepe brojku od 700.000 žrtava koriste s krajnjim oprezom. Knjiga Jasenovac I. Goldsteina pokazuje što se dobiva kada se to zanemari.

„Za razliku od Goldsteina, ja ne znam koliki je broj jasenovačkih žrtava, niti se to usuđujem tvrditi. Ali za razliku od raznih šarlatana koji uporno ponavljaju brojku od više stotina tisuća pa do milijuna jasenovačkih žrtava, ili pak ta stradanja umanjuju na gotovo zanemarive brojke i tek koju tisuću žrtava i opravdavaju ih na sve načine, svjestan sam da je riječ o nemalim, štoviše da se radi o velikim razmjerima ljudskih stradanja",

komentar je povjesničara Vladimira Geigera, koji se bavi problematikom žrtava u ratu i poraću. ${ }^{117}$

Tretman Jasenovca danas ilustriraju dvije knjige objavljene 2018. godine: Radni logor Jasenovac politologa i novinara Igora Vukića i Jasenovac sveučilišnoga profesora, profesionalnoga povjesničara Ive Goldsteina. ${ }^{118}$ Vukićevu knjigu politologinja M. Kasapović nazvala je „toksikološkim šundom”. ${ }^{119} \mathrm{U}$ kraćem prikazu povjesničar V. Geiger nazvao je Goldsteinovu knjigu „kapitalnim djelom hrvatske trivijalne historiografije”. ${ }^{120}$ U kasnijem prikazu temeljito je naveo propuste i manipulacije, pa je očito da je Goldsteinova knjiga potpuni

${ }^{116}$ EAGLESTONE, Postmodernizam i poricanje holokausta, 56-57.

117 GEIGER, „Ivo Goldstein, Jasenovac”, 303.

118 VUKIĆ, Radni logor Jasenovac; I. GOLDSTEIN, Jasenovac.

119 Mirjana KASAPOVIĆ, „Vukićeva knjiga o Jasenovcu toksični je šund: Kakve mu god bile intencije, napisao je proustaško pseudohistoriografsko djelo", Globus, on-line izdanje, 15. 12. 2018., pristup ostvaren 5. 2. 2019., https://www.jutarnji.hr/globus/Globus-komentari/m-kasapovic-za-globus-vukiceva-knjiga-o-jasenovcu-toksicni-je-sund-kakve-mu-god-bile-intencijenapisao-je-proustasko-pseudohistoriografsko-djelo/8180114/; Igor VUKIĆ, „Prof. Kasapović želi zaustaviti svako propitivanje dogovorene povijesti Jasenovca”, Hrvatski tjednik (Zadar), online izdanje, 7. 1. 2019., pristup ostvaren 5. 2. 2019., https://www.hkv.hr/hrvatski-tjednik/30999odgovor-na-osvrt-komentar-mirjane-kasapovic-na-knjigu-radni-logor-jasenovac.html.

120 Vladimir GEIGER, „Kapitalno djelo hrvatske trivijalne historiografije”, Politički zatvorenik (Zagreb), br. 277, listopad-prosinac 2018., 12-17. Članak dostupan i na: https://www.hkv.hr/ domovini/2-svjetski-rat/31131-ivo-goldstein-jasenovac-kapitalno-djelo-hrvatske-trivijalne-historiografije.html. 
promašaj. ${ }^{121}$ No to očito ne zabrinjava apologete koji ju hvale ${ }^{122}$ ili relativiziraju njezin sadržaj pod pojmom afirmativnih i kritičkih prikaza. ${ }^{123}$ Takav pristup zabrinjava jer pokazuje da nije bitan sadržaj nego forma, nije bitno što se govori nego tko govori, posebice ako s „nama” dijeli isti ili sličan svjetonazor. U tom kontekstu apsurdno je zbog Goldsteinove knjige postavljati pitanje „Što poslije", kao na apologetskoj tribini održanoj 13. prosinca 2018. na Filozofskom fakultetu u Zagrebu. U tjedniku Nacional o tome je zabilježeno:

„U vijećnici Filozofskog fakulteta u Zagrebu okupili su se povjesničari i upravitelji Jasenovačkog muzeja kako bi odgovorili na pitanje što nakon izlaska Goldsteinove knjige? Na koji način mi, kao društvo, moramo kročiti u budućnosti sada kada smo utvrdili neke činjenice? Jednostavnog odgovora nije bilo, no svi su se složili da revizionizam i dalje predstavlja veliku prijetnju društvu i napretku." 124

Opširni prikaz knjige V. Geigera daje putokaz, no to je vrsta sugestija koja se prešućuje i minorizira. Nije isključeno da će se primijeniti formula koju je osobno I. Goldstein spomenuo 31. svibnja 2019. na predstavljanju knjige Jasenovac u Banjoj Luci, „kako mu zapravo uopće nije cilj baviti se revizionistima i 'njihovim glupostima i lažima"'. ${ }^{125}$

Što se tiče pitanja broja jasenovačkih žrtava, s jedne se strane smatra da je vrlo malen, pa se ide i do krajnosti da su žrtve izmišljene, a s druge strane stižu optužbe za revizionizam i odbacivanje zahtjeva za utvrđivanje njihova broja. Tu opet prednjači I. Goldstein, koji tvrdi da je to besmisleno, da nema elemenata, da je arhiva uništena, da su korištene peći za spaljivanje leševa, pa čak i da su kosti žrtava drobljene posebnim strojevima dovezenim iz Njemačke. ${ }^{126} \mathrm{~S}$ obzirom na takav pristup, ne slažem se s mišljenjem da je „javno znanje o Jasenovcu" koje prevladava na desnoj opciji društva rezultat negativnoga odnosa prema „totalitarnoj komunističkoj Jugoslaviji”, kao što primjerice smatra B. Janković. ${ }^{127}$ Doprinos su dali i „ugledni”, ali neodgovorni povjesničari spremni na izmišljanja i lako dokazive manipulacije.

${ }^{121}$ GEIGER, „Ivo Goldstein, Jasenovac”, 269-337.

122 „Ivo Goldstein: Jasenovac”.

123 „Afirmativne i kritičke ocjene knjige Ive Goldsteina 'Jasenovac”'.

${ }^{124}$ Igor JURDANA, „Jasenovac: Revizionizam i činjenice”, Nacional (Zagreb), on-line izdanje, 15. 12. 2018., pristup ostvaren 29. 5. 2019., https://www.nacional.hr/jasenovac-revizionizam-icinjenice/.

125 Z. K. / HINA, „Goldstein: Jasenovac je kompleksna priča i licitiranje brojem žrtava je nedopustivo”; „Održan History Fest”.

126 ŠTAVLJANIN, „Ivo Goldstein: Istinu o Jasenovcu zna svatko tko želi”; Ivo GOLDSTEIN, „Komisija za Jasenovac: nova besmislena inicijativa šefice države”, Globus, on-line izdanje, 5. 5. 2018., pristup ostvaren 16. 6. 2019., https://www.jutarnji.hr/globus/Globus-komentari/piseivo-goldstein-komisija-za-jasenovac-nova-besmislena-inicijativa-sefice-drzave/7321071/. Usp. GEIGER, „Ivo Goldstein, Jasenovac”, 309-310.

${ }^{127}$ JANKOVIĆ, „Javni status znanja o Jasenovcu ili kako je javna povijest porazila akademsku historiografiju”. 
Koliko je revizija broja žrtava nužna da bi se manipulacije svele na minimum, uz paradigmatski slučaj Jasenovca naveo bih i slučaj ustaškoga logora Jadovno. Premda broj žrtava nije ustanovljen, u optjecaju je tvrdnja o minimalno 10.000 žrtava, čiji je identitet navodno utvrdio Đuro Zatezalo. ${ }^{128}$ No, problem je mnogo kompleksniji, na što je već skrenuta pozornost, što se naravno ignorira. ${ }^{129}$ Naveo bih i jedan manje poznat, ali indikativan primjer koji sam uočio tijekom rada na ovom članku. Novosti, glasilo Srpskoga nacionalnog vijeća, sredinom svibnja 2019. objavile su vijest da je preminuo „partizanski veteran i antifašistički aktivist" Sulejman Muhamedagić Sula, koji je bio jedan najvećih „zagovornika obnove komemoracija na tzv. Mehinom stanju gdje je početkom 1941. ubijeno preko $4.100 \mathrm{Srba}$, a koje su bile zamrle tokom rata u Bosni i Hercegovini”. ${ }^{130} \mathrm{Na}$ internetskom portalu udruženja građana Jadovno 1941. može se naći podatak da je 1956. na njivi Mehino stanje [u općini Slunj na granici s Velikom Kladušom] podignuta ploča u spomen na 2400 osoba ubijenih u kolovozu 1941. godine. ${ }^{131}$ Ostavljajući po strani netočnu tvrdnju da je zločin počinjen početkom 1941., autor članka u Novostima izabrao je najveću brojku žrtava, no utemeljeno je zapitati se koja je točna i je li i na Mehino stanje primijenjena praksa preuveličavanja žrtava kao u slučaju Jasenovca? To je još jedan pokazatelj problema na koji historiografija treba odgovoriti.

\section{Drugi svjetski rat kao polje revizionizma}

Zastupljenost povijesti u javnoj sferi tek je s komunizmom doživjela „procvat". Prošlost je za komuniste imala veliko ideološko značenje, posebice ona od 1941., uz naravno povijest KPJ i partizanskoga pokreta. S obzirom na to da su mediji bili u rukama Partije, tj. neke od njezinih transmisija u društveno-političkim zajednicama ili organizacijama, prostor je bio strogo nadziran i otvoren samo za istomišljenike koji su dijelili osnovne značajke partijskoga svjetonazora.

Prelazak u višestranačje 1990. otvorio je priliku da o Drugom svjetskom ratu u domovini nešto kaže i gubitnička strana, a ne kao do tada samo u emigraciji. Ona je tada prvi put imala priliku ponuditi, doduše selektivno i na marginama, svoje viđenje Drugoga svjetskog rata. ${ }^{132} \mathrm{U}$ javnost je isplivalo doslovno svašta, a najveći potres izazvala su saznanja o masovnim komunističkim zločinima u samoj završnici rata i poraću, koji su prihvaćeni u široku uporabu

\footnotetext{
${ }^{128}$ „U nedjelju se obilježava Dan sjećanja na Jadovno 1941., Novosti, on-line izdanje, 19. 6. 2019., pristup ostvaren 22. 6. 2019., https://www.portalnovosti.com/u-nedjelju-se-obiljezavadan-sjecanja-na-jadovno-1941.

129 GEIGER, JAREB, KOVAČIĆ, Jadovno i Šaranova jama.

${ }_{130}$ M. C., „In memoriam Sulejman Muhamedagić Sula: Borac do kraja”, Novosti, on-line izdanje, 14. 5. 2019., pristup ostvaren 16. 5. 2019., https://www.portalnovosti.com/in-memoriamsulejman-muhamedagic-sula-borac-do-kraja.

131 „Masovna grobnica Mehino stanje”.

${ }^{132}$ CIPEK, „Sjećanje na 1945: čuvanje i brisanje”, 158-160.
} 
kao Bleiburg i križni put. Ta su stradanja desetljećima bila potpuno prešućena, što je u suprotnošću s aktualnim tvrdnjama „slijeva” da nije bilo komunističkih zločina. Nastojanje da se ti zločini svedu na „osvetnički gnjev” iz iste je vrste pobude koja relativizira ustaške zločine. ${ }^{133}$ Pritom se zanemaruje suština komunizma, kontinuitet njihovih zločina i represalija od 1941. do 1945. ili, da pojednostavnimo, od ubojstva antifašista i trockista Živojina Pavlovića 1941. u Užicu, preko „lijevih skretanja” u Crnoj Gori i istočnoj Hercegovini 1942. do Kočevskog roga i Hude jame 1945. u Sloveniji. ${ }^{134}$ Koliko je tendenciozno uspoređivati kažnjavanje kolaboracionista na Zapadu s onim na Istoku, gdje se paralelno provodila i socijalistička revolucija, vidi se iz nedavno objavljenog rada V. Geigera i Suzane Leček. ${ }^{135}$ U Jugoslaviji (i Hrvatskoj) taj je obračun bio uvjerljivo najoštriji, što baca jako svjetlo na pokušaje da ga se relativizira umanjivanjima tipa „osvetničkoga gnjeva”. I tu dolazimo do jedne bitne značajke prethodnoga razdoblja koja se ne može ignorirati, a to se često čini u ovakvim raspravama. S jedne strane Jasenovac, koji je predimenzioniran, a s druge strane Bleiburg, koji je potpuno prešućen. Relativiziranje komunističkih zločina i dalje se nastavlja tvrdnjom da je to neusporedivo, što simbolizira i knjiga Jasenovac i Bleiburg nisu isto. ${ }^{136}$ Nezavisna Država Hrvatska svodi se samo na ustaše, čime se sustavno nameće koncept kolektivne krivnje svima koji rat nisu završili u partizanima. Jedan od primarnih „revizionističkih” zadataka jest odgovoriti na pitanje svakodnevnoga života u dijelu Hrvatske pod nadzorom tijela vlasti NDH. Jesu li svi oni koji nisu otišli u šumu odgovorni za ustaške zločine, uključujući i one koji su nastojali ostati po strani od participiranja u ratu u bilo kojoj vojsci i koji su samo nastojali preživjeti rat? Tu naravno imamo široko nijansirano područje, od optužbi da je oduševljenje novom hrvatskom državom krimen, pri čemu im se imputira da su „morali” znati u što će se to pretvoriti. To je optužba iz 15. svibnja 1945. za sudjelovanje u slavlju proglašenja NDH 10. travnja 1941. godine. Postojale su osobe koje su izrazile lojalnost, prigrlile sustav i ostale u njemu do kraja. No bilo je i onih koji to nisu učinili. Pritom valja imati na pameti i temeljno političko organiziranje. Ustaše su zabranili sve političke opcije, uključujući i HSS, pa je politički organizirano stanovništvo na teritoriju pod nadzorom vlasti NDH moglo biti samo $\mathrm{u}$ članstvu Ustaše, tj. u njihovu pokretu koji je nastojao dobiti širi legitimitet u stanovništvu. Taj se „legitimitet” kupovao privilegijima, što je posebice važno u slučaju vojnoga organiziranja. Ustaška vojnica bila je privlačnija zbog boljega logističkog osiguranja i opcije koja se zanemaruje, premda se time nije ni bavilo, da se kadrovski rok služi blizu kućnoga praga, a po njegovu odsluženju

133 S. GOLDSTEIN, I. GOLDSTEIN, Jasenovac i Bleiburg nisu isto, 145-146, 159, 167-200.

${ }^{134}$ LASIĆ, Krležologija: O moralnoj strukturi i totalitarnoj svijesti; PETRANOVIĆ, Srbija u Drugom svetskom ratu 1939-1945, 297-306; FERENC, KUŽATKO, Prikrivena grobišta Hrvata u Republici Sloveniji.

${ }^{135}$ GEIGER, LEČEK, „Politika retribucije u Europi nakon Drugog svjetskog rata”, 7-34.

${ }^{136}$ S. GOLDSTEIN, I. GOLDSTEIN, Jasenovac i Bleiburg nisu isto. 
postoji prednost pri zapošljavanju. ${ }^{137}$ Stoga se taj aspekt ne može ignorirati pri razmatranju motiva za pristupanje Ustaškom pokretu.

Oko problematike istraživanja NDH u odnosu na stanje do 1990. napravljen je izvjestan iskorak. Možemo reći da imamo utemeljenija saznanja o življenju u njoj premda smo još daleko od opće slike. Znamo ponešto više od odnosu prema Muslimanima, o vojnoj organizaciji i nekim aspektima politike u Dalmaciji. Ne treba strahovati da će rasne zakone, teror i slično dovesti u pitanje profesionalna historiografija koja bez prizemnih kalkulacija istražuje tu problematiku. Nezavisna Država Hrvatska bila je saveznica sila Osovine i to ju trajno definira, ta se činjenica ne može relativizirati ma koliko se tvrdi da se to radi.

Na sarajevskom skupu o reviziji prošlosti od Goldsteinova ponavljanja radova s početka XXI. stoljeća veću pozornost zaslužuje rad povjesničarke Emily Greble-Balić. Ona smatra da je historiografija o Drugom svjetskom ratu ostala na istim koordinatama kao prije rata i raspada SFRJ. Konstatirala je da „ukoliko želimo razumjeti prirodu rata i društvenih transformacija koje su se odigrale u Bosni i Hercegovini tokom 40-ih godina dvadesetog stoljeća, neophodno je uzeti potpuno drugačiji pristup u odnosu na većinu historija ovog područja”. ${ }^{138}$

No, participacija u sustavu NDH poticajna je za sličnu usporedbu sa stanjem u socijalističkoj Jugoslaviji i participiranjem mase u KPJ/SKJ. Sličnosti su vrlo velike. I u tom se slučaju javlja pitanje onih koji su nastojali biti izvan toka, tj. izvan sustava. Jesu li takvi bili „bastion morala” u djelovanju Tita i drugova, koje bi jedan recentni međunarodni politički sud sa sjedištem u Nizozemskoj nazvao udruženim zločinačkim pothvatom? Problematika „povijesnoga revizionizma" oko jednoga totalitarizma otvara niz drugih historiografskih problema važnih za proučavanje suvremene povijesti. Ako je stavljanje ustaških zločina i stvarnoga karaktera NDH na pravu mjeru povijesni revizionizam, kako nazvati negiranje komunističkih zločina i stvarnoga karaktera druge, socijalističke Jugoslavije, čiji je integralni dio bila i Hrvatska? Jesu li komunisti i njihova država uopće bili problematični ili se radi o neutemeljenom skretanju pozornosti javnosti na nekoliko navodno nevažnih ekscesa koji su se zbili dok je Tito s Partijom gradio bolje društvo od kojega smo svi profitirali, što znaju natuknuti s krajnje lijevoga spektra, što je i poziv da se šuti i ne postavlja pitanje što smo bili tijekom pothvata Tita i njegovih suradnika? ${ }^{139}$ Koliko je

\footnotetext{
${ }^{137}$ MARIJAN, „Između želje i stvarnosti: ustaša u bojnoj odori”, 340-344.

${ }^{138}$ GREBLE-BALIĆ, „Preispitivanje historije i historiografije Jugoslavije”, 165.

${ }_{139}$ Pod tim mislim i na sebe jer sam, kako to sugerira novinar Damir Pilić s krajnje lijevoga političkog spektra, zahvaljujući komunistima bio u prilici provinciju zamijeniti velegradom i lagodnim životom povjesničara na nacionalnom institutu za povijest. Damir PILIĆ, „Reagiranje na članak dr. Davora Marijana 'S Titovom smo vlašću upali u barbarstvo' - Barbari su zaustavili civilizacijski sunovrat”, Slobodna Dalmacija, 10. 2. 2018., preneseno na portalu Udruga antifašista Dubrovnik, pristup ostvaren 2. 2. 2019., https://www.uafdu.hr/reagiranje-na-clanakdr-davora-marijana-s-titovom-smo-vlascu-upali-u-barbarstvo-barbari-su-zaustavili-civilizacijski-sunovrat-pise-damir-pilic/. Sličan komentar dala je 2017. književnica Vedrana Rudan za sveučilišnoga profesora i kolumnista Ninu Raspudića. RUDAN, „Pionir Raspudić, Nino Raspudić”.
} 
malo potrebno za iskorak u krajnost svjedoči polemika Ive Banca sa stajalištima predsjednika Republike Hrvatske Stjepana Mesića o antifašizmu s početka 2008. godine. Publicist Ivo Horvat optužio je Banca da polemikom s Mesićem „legitimira 'revizioniste’ poput [Josipa] Jurčevića i pridonosi snaženju desnice. Dakle”, naglasio je Banac,

„nije važno imam li argumente za svoje stavove, nego hoće li oni 'objektivno' pomoći 'neprijatelju'. Takav oblik instrumentalizacije znanosti tipičan je za komuniste i jedan je od razloga zašto kod nas još ne postoji kritička literatura o fenomenu komunizma". ${ }^{140}$

\section{Zaključak}

Povijesni revizionizam pojam je novijega postanka, osjetno mlađi od Republike Hrvatske. U socijalizmu je revizionizam bio rezerviran isključivo za sferu marksizma, stoga ne čudi da nema povijesnoga rada o revizionizmu do 1990. godine. Sve što se o revizionizmu pisalo bila je ideologija i bilo je usmjereno protiv onih koji su smatrali da se u komunizam može bez socijalističke revolucije. Devedesetih godina promijenila se vlast u Hrvatskoj, zbio se rat koji kao izvanredno stanje nije bio pogodan za normalan život, pa ni historiografska istraživanja. Historiografija nije zamrla, a nakon 2000. dio nje etiketiran je povijesnim revizionizmom, a prvi hrvatski predsjednik Franjo Tuđman prozivan najodgovornijim za njega. „Otac” prozivanja za povijesni revizionizam bio je Tuđmanov politički protivnik Slavko Goldstein, osoba bez formalnoga povijesnog obrazovanja, i njegov slučaj pokazuje kako dobro umreženi medijski interesi mogu od besmislice napraviti pitanje „životne važnosti”, da ne kažemo nacionalnoga interesa. Međutim, njegove su teze neprihvatljive u znanosti. Prozivanja za revizionizam u znanosti, pa tako i u historiografiji, apsurdna su jer, kako primjećuje M. Gross, „svaki iskaz zastaruje i zahtijeva reviziju”. Što je znanost bez revizije? Jesu li znanstvenici koji rade reviziju revizori ili revizionisti - pitanje je za uzaludno gubljenje vremena.

$\mathrm{Na}$ kraju, očito je da se pojam povijesnoga revizionizma javlja u krugovima kojima je i pojam revizionizma bio blizak, a to su krugovi koji ne vide nikakvu potrebu ni smisao dovođenja u pitanje slike Drugoga svjetskog rata koja je stvarana do 1990. godine. Iznimka je samo brojka od 700.000 žrtava Jasenovca, koja je umanjena i kreće se u rasponu od 83 do 100 tisuća. Ni te brojke nisu ustvari rezultat istraživačkoga rada, odnosno nisu utemeljene na provjerljivim i nedvojbenim izvorima, no upornim ponavljanjem prihvaćene su u dijelu hrvatskoga društva. Sve ostalo uglavnom je isto, kako bi se moglo zaključiti u sferi povijesnoga dobra nasuprot povijesnom zlu. Prozivanje za povijesni revizionizam ima nakanu da se stanje hibernira, a potencijalni istraživači obeshrabre. To je sfera dnevne politike, ali ne i znanosti.

\footnotetext{
${ }^{140}$ Ivo BANAC, „O komunističkom antifašizmu”, Jutarnji list, 8. 3. 2008., 74.
} 
Povjesničari koji nisu revizionisti nemaju što tražiti u znanosti. Bilo bi korektnije prema poreznim obveznicima da ustupe prostor onima koji ne robuju formi, nisu lijeni zaroniti $u$ arhive i ne boje se stalnoga propitivanja. ${ }^{141}$ Oni drugi trebali bi se angažirati u nekoj od mnogih političkih opcija koje im stoje na raspolaganju.

\section{Arhivski i neobjavljeni izvori}

HR-HDA-1220-CK SKH: Hrvatska, Hrvatski državni arhiv, Zagreb, fond 1220, Centralni komitet Saveza komunista Hrvatske.

\section{Objavljeni izvori i tisak}

Deklaracija o genocidu Nezavisne Države Hrvatske nad Srbima, Jevrejima $i$ Romima tokom Drugog svjetskog rata, Peta međunarodna konferencija o Jasenovcu 24.-25. maj 2011. Banja Luka: Udruženje „Jasenovac - Donja Gradina”, 2011.

Odluke I. općeg sabora HDZ. Programske zasade i ciljevi HDZ. Statut HDZ. Izborni proglas. Izabrana tijela HDZ. Zagreb: Hrvatska demokratska zajednica, 1990.

„Poimenični popis žrtava KCL Jasenovac”. Spomen-područje Jasenovac. Pristup ostvaren 14. 6. 2019. http://www.jusp-jasenovac.hr/Default.aspx?sid=6284.

Globus (Zagreb), 1999-2000, 2017-2018.

Hrvatski tjednik (Zadar), 2019.

Jutarnji list (Zagreb), 2001, 2008, 2012, 2016, 2019.

Nacional (Zagreb), 2018.

Narodne novine (Zagreb), 146 (2005).

Nedjeljni Jutarnji (Zagreb), 2007.

Novi list (Rijeka), 2015-2017.

Novosti (Zagreb), 2018-2019.

Politički zatvorenik (Zagreb), 2018.

Preporodov Journal (Zagreb), 2019.

Slobodna Dalmacija (Split), 2018.

Večernji list: Obzor (Zagreb), 2011.

${ }^{141}$ Svjež primjer takva pristupa je: BERGHOLZ, Nasilje kao generativna sila. 


\section{Literatura}

"Afirmativne i kritičke ocjene knjige Ive Goldsteina 'Jasenovac". Portal Historiografija.hr (Zagreb), 8. 6. 2019. Pristup ostvaren 12. 6. 2019. http://www. historiografija.hr/?p=15195.

BANAC, Ivo. „Rat prije rata: raspad jugoslavenske historiografije”. U: Cijena Bosne: članci, izjave i javni nastupi, 1992.-1993. Zagreb: „Europa danas”, 1994., 14-33.

BARIĆ, Nikica. „Antifašistička borba u Drugom svjetskom ratu u političkim interpretacijama hrvatskih predsjednika 1991-2006." U: Revizija prošlosti na prostorima bivše Jugoslavije: zbornik radova, ur. Vera Katz. Sarajevo: Institut za istoriju, 2007, 211-233.

BARIĆ, Nikica. „Prvi hrvatski predsjednik dr. Franjo Tuđman o jugoslavenskom predsjedniku Josipu Brozu Titu". U: Dr. Franjo Tudman u okviru hrvatske historiografije, ur. Vijoleta Herman Kaurić. Zagreb: Hrvatski institut za povijest; Hrvatski institut za povijest, Podružnica za povijest Slavonije, Srijema i Baranje, 2011, 313-340.

BERGHOLZ, Max. Nasilje kao generativna sila. Identitet, nacionalizam $i$ sjećanje u jednoj balkanskoj zajednici. Sarajevo; Zagreb: Buybook, 2018.

BILANDŽIĆ, Dušan. Historija Socijalističke Federativne Republike Jugoslavije. Glavni procesi 1918-1985. Zagreb: Školska knjiga, 1985.

BILANDŽIĆ, Dušan. Hrvatska moderna povijest. Zagreb: Golden marketing, 1999.

BILANDŽIĆ, Dušan; JELIĆ, Ivan; MATKOVIĆ, Hrvoje; PAVLIČEVIĆ, Dragutin; STANČIĆ, Nikša; VUKADINOVIĆ, Radovan. Povijest 2. Zagreb: Školska knjiga, ${ }^{3} 1988$.

BILANDŽIĆ, Dušan; KASAPOVIĆ, Mirjana; BABIĆ, Kornelija. Marksizam i socijalističko samoupravljanje 2. Zagreb: Školska knjiga, 1986.

BOBAN, Ljubo. Kontroverze iz povijesti Jugoslavije, knj. 1 i 2 . Zagreb: Školska knjiga; Stvarnost, 1989.

BOGDANIĆ, Luka. „Ideološki Trompe-l’oeil ili historijski revizionizam”. U: Domenico Losurdo, Historijski revizionizam. Problemi i mitovi. Zagreb: Prosvjeta, 2017, 5-7.

BOUGAREL, Xavier. „Od krivičnog zakona do Memoranduma. Upotreba pojma 'genocid' u komunističkoj Jugoslaviji”. Političke perspektive 1 (2011), br. 2: 7-23.

BROZ TITO, Josip. „Politički izvještaj”. U: V. kongres Komunističke partije Jugoslavije. Izveštaji i referati. Zagreb: Kultura, 1948, 7-166.

BUDAK, Neven. „Post-socialist Historiography in Croatia since 1990”. U: (Re)Writing History: Historiography in southeastern Europe after Socialism, ur. Ulf Brunnbauer. Münster: Lit. Verlag, 2004, 128-164. 
CIPEK, Tihomir. „Politike povijesti u Republici Hrvatskoj: Od 'puška puče' do 'Hristos se rodi"'. U: Kultura sjećanja: 1918. Povijesni lomovi i svladavanje prošlosti. Zagreb: Disput, 2007, 13-26.

CIPEK, Tihomir. „Sjećanje na 1945: čuvanje i brisanje”. U: Kultura sjećanja: 1945. Povijesni lomovi i svladavanje prošlosti. Zagreb: Disput, 2009, 155-165.

DEDIJER, Vladimir. Novi prilozi za biografiju Josipa Broza Tita 2. Rijeka; Zagreb: GRO „Liburnija”; IKRO „Mladost”, 1981.

ĐURETIĆ, Veselin. Saveznici i jugoslovenska ratna drama. Beograd: Narodna knjiga; Balkanološki institut SANU, 1985.

EAGLESTONE, Robert. Postmodernizam i poricanje holokausta. Zagreb: Naklada Jesenski i Turk, 2001.

FERENC, Mitja; KUŽATKO, Želimir. Prikrivena grobišta Hrvata u Republici Sloveniji. Zagreb: Počasni bleiburški vod, 2017.

GEIGER, Vladimir. „Ivo Goldstein, Jasenovac (Zaprešić; Jasenovac: Fraktura; Javna ustanova Spomen-područje Jasenovac, 2018)”. Časopis za suvremenu povijest 51 (2019), br. 1: 269-337.

GEIGER, Vladimir; JAREB, Mario; KOVAČIĆ, Davor. Jadovno i Šaranova jama. Kontroverze i manipulacije. Zagreb: Hrvatski institut za povijest, 2017.

GEIGER, Vladimir; LEČEK, Suzana. „Politika retribucije u Europi nakon Drugog svjetskog rata”. Časopis za suvremenu povijest 50 (2018), br. 1: 7-34.

GOATI, Vladimir. SKJ, kriza, demokratija. Zagreb: CEKADE, 1986.

GOLDSTEIN, Ivo; [suautor GOLDSTEIN, Slavko]. Holokaust u Zagrebu. Zagreb: Novi Liber; Židovska općina Zagreb, 2001.

GOLDSTEIN, Ivo. Jasenovac. Zagreb: Fraktura, 2018.

GOLDSTEIN, Ivo. „O antifašizmu jučer, danas i sutra”. U: Antisemitizam, holokaust, antifašizam. Zagreb: Židovska općina Zagreb, 1996, 285-289.

GOLDSTEIN, Ivo. „Od partijnosti u doba socijalizma do revizionizma devedesetih: Ima li građanska historiografija šansu?” U: Hrvatska historiografija XX. stoljeća. Između znanstvenih paradigmi i ideoloških zahtjeva, ur. Srećko Lipovčan i Ljiljana Dobrovšak. Zagreb: Institut društvenih znanosti „Ivo Pilar”, 2005, 57-72.

GOLDSTEIN, Ivo. „Upotreba povijesti”. Erasmus (1993), br. 1: 52-61.

GOLDSTEIN, Ivo; HUTINEC, Goran. „Neki aspekti revizionizma u hrvatskoj historiografiji devedesetih godina XX. stoljeća - metode, motivi i odjeci”. U: Revizija prošlosti na prostorima bivše Jugoslavije: zbornik radova, ur. Vera Katz. Sarajevo: Institut za istoriju, 2007, 187-210.

GOLDSTEIN, Slavko; GOLDSTEIN, Ivo. Jasenovac i Bleiburg nisu isto. Zagreb: Novi Liber, 2011.

GREBLE-BALIĆ, Emily. „Preispitivanje historije i historiografije Jugoslavije tokom Drugog svjetskog rata: slučaj Sarajeva”. U: Revizija prošlosti na prostorima bivše Jugoslavije: zbornik radova, ur. Vera Katz. Sarajevo: Institut za istoriju, 2007, 163-172. 
GROSS, Mirjana. Historijska znanost. Zagreb: Sveučilišna naklada Liber, 1980.

GROSS, Mirjana. Suvremena historiografija: korijeni, postignuća, traganja. Zagreb: Novi Liber, ${ }^{2} 2001$.

Historija i suvremenost. Idejne kontroverze. Zagreb: Centar CK SKH za idejno-teorijski rad „Vladimir Bakarić”; ČGP „Delo”; OOUR Globus, 1984.

IVELJIĆ, Iskra. „Hrvatska historiografija o 19. stoljeću nakon raspada Jugoslavije”. Prispevki za novejšo zgodovino XLIV (2004), br. 2: 29-44.

„Ivo Goldstein: Jasenovac”. Portal artegalerija.rs (Beograd), 27. 3. 2019. Pristup ostvaren 8. 4. 2019. http://www.arte.rs/sr/vesti/ivo_goldstein_jasenovac-12596/.

JANEKOVIĆ RÖMER, Zdenka. „Problem revizije u povijesnoj znanosti”. U: Historiografija/povijest u suvremenom društvu, ur. Gordan Ravančić, Mislav Gregl, Ivana Horbec, Vlasta Švoger i Dinko Župan. Zagreb: Hrvatski institut za povijest, 2014, 127-136.

JANKOVIĆ, Branimir. „Javni status znanja o Jasenovcu ili kako je javna povijest porazila akademsku historiografiju”. Portal Historiografija.hr (Zagreb), 24. 12. 2018. Pristup ostvaren 14. 6. 2019. http://www.historiografija.hr/?p=12985.

JANKOVIĆ, Branimir. Mijenjanje sebe same. Preobrazbe hrvatske historiografije kasnog socijalizma. Zagreb: Srednja Europa, 2016.

„Jasenovac”. U: Enciklopedija Jugoslavije, sv. 4. Zagreb: Izdanje i naklada Leksikografskog zavoda FNRJ, 1960, 467.

JELIĆ, Ivan. Tragedija u Kerestincu. Zagrebačko ljeto 1941. Zagreb: Globus, 1986.

JOVIĆ, Dejan. Rat i mit. Politika identiteta u suvremenoj Hrvatskoj. Zagreb: Fraktura, ${ }^{2} 2018$.

KAMBEROVIĆ, Husnija. „Prva kvalitetna sinteza historije Bosne i Hercegovine za vrijeme Drugog svjetskog rata”. U: Rasim Hurem, Bosna i Hercegovina u Drugom svjetskom ratu 1941-1945. Zagreb; Sarajevo: Plejada; BNZGUniversity Press, 2016, 7-12.

KASAPOVIĆ, Mirjana. „Dvojac bez kormilara: odgovor na istupe Dragutina Lalovića i Daga Strpića na znanstvenom skupu 'Stanje i povijest političke znanosti u državama bivše Jugoslavije”. Anali Hrvatskog politološkog društva 5 (2008), br. 1: 145-164.

KASAPOVIĆ, Mirjana. „Genocid u NDH: Umanjivanje, banaliziranje i poricanje zločina”. Politička misao 55 (2018), br. 1: 7-33.

KLASIĆ, Hrvoje. „Tri najveće revizionističke laži o Jasenovcu: O ustaškom logoru smrti sve se zna, a teze naših mitomana pokazuju i koliko su licemjerni”. Portal net.hr (Zagreb), 23. 4. 2019. Pristup ostvaren 29. 5. 2019. https://net. $\mathrm{hr} /$ danas/hrvatska/tri-najvece-revizionisticke-lazi-o-jasenovcu-o-ustaskomlogoru-smrti-sve-se-zna-a-teze-nasih-mitomana-pokazuju-i-koliko-su-licemjerni/. 
„KLASIĆ: u Hrvatskoj i Srbiji na djelu tipičan revizionizam”. Al Jazeera Balkans (Sarajevo), 4. 2. 2019. Pristup ostvaren 29. 5. 2019. http://balkans.aljazeera.net/vijesti/klasic-u-hrvatskoj-i-srbiji-na-djelu-tipican-revizionizam.

KOČOVIĆ, Bogoljub. Žrtve Drugog svetskog rata u Jugoslaviji. Sarajevo: Svjetlost, 1990.

KOREN, Snježana. Politika povijesti u Jugoslaviji (1945-1960). Komunistička partija Jugoslavije, nastava povijesti, historiografija. Zagreb: Srednja Europa, 2012.

KORUNIĆ, Petar. „Povijesna struka i kritika hrvatske historiografije danas”. Radovi Zavoda za hrvatsku povijest 31 (1998), br. 1: 167-179.

KOŠTUNICA, Vojislav; ČAVOŠKI, Kosta. Stranački pluralizam ili monizam. Društveni pokreti i politički sistem u Jugoslaviji 1944-1949. Beograd: Institut društvenih nauka Univerziteta u Beogradu; Centar za filozofiju i društvenu teoriju, 1983.

KRIŠTO, Jure. „Ideologija/politika i historiografija: primjer Časopisa za suvremenu povijest (1969.-1999.)". U: Hrvatska historiografija XX. stoljeća. Između znanstvenih paradigmi i ideoloških zahtjeva, ur. Srećko Lipovčan i Ljiljana Dobrovšak. Zagreb: Institut društvenih znanosti „Ivo Pilar”, 2005, 73-98.

KRIŠTO, Jure. „Još jedanput o knjizi Holokaust u Zagrebu”. Časopis za suvremenu povijest 34 (2002), br. 3: 961-985.

LASIĆ, Stanko. Krležologija ili povijest kritičke misli o Miroslavu Krleži: O moralnoj strukturi i totalitarnoj svijesti. Zagreb: Globus, 1989.

LEKOVIĆ, Mišo. „O nekim slabostima historijske nauke”. U: Historija $i$ suvremenost. Idejne kontroverze. Zagreb: Centar CK SKH za idejno-teorijski rad „Vladimir Bakaric”; ČGP „Delo”; OOUR Globus, 1984, 138-145.

LOSURDO, Domenico. Historijski revizionizam. Problemi i mitovi. Zagreb: Prosvjeta, 2017.

MARIJAN, Davor. Hrvatska 1989. - 1992. Rađanje države. Zagreb: Hrvatski institut za povijest, 2017.

MARIJAN, Davor. „Između želje i stvarnosti: ustaša u bojnoj odori”. Časopis za suvremenu povijest 50 (2018), br. 2: 337-362.

„Masovna grobnica Mehino stanje”. Udruženje potomaka i poštovalaca žrtava kompleksa logora smrti NDH, Gospić-Jadovno-Pag 1941. Pristup ostvaren 16. 5. 2019. http://www.jadovno.com/arhiva/eng-lat-493/articles/masovna-grobnica-mehino-stanje-9189.html.

MATICKA, Marijan. „O istraživanju povijesti Nezavisne Države Hrvatske”. Radovi Zavoda za hrvatsku povijest 28 (1995), br. 1: 254-257.

MATKOVIĆ, Stjepan. „Razgovor s prof. dr. Hrvojem Matkovićem u povodu 80. godišnjice njegova života”. Časopis za suvremenu povijest 35 (2003), br. 3: 997-1028. 
NAJBAR-AGIČIĆ, Magdalena. U skladu s marksizmom ili činjenicama? Hrvatska historiografija 1945-1960. Zagreb: Ibis grafika, 2013.

NIKOLIĆ, Kosta. Prošlost bez istorije. Polemike u jugoslovenskoj istoriografiji 1961-1991. Glavni tokovi. Beograd: Institut za savremenu istoriju, 2013.

„Odgovor Stjepana Loze Hrvoju Klasiću i Damiru Piliću: 'Sramota kakvi pojedinci predaju na Filozofskom fakultetu i deformiraju nove generacije hrvatskih povjesničara"'. Portal narod.hr (Zagreb), 20. 11. 2018. Pristup ostvaren 14. 6. 2019. https://narod.hr/hrvatska/odgovor-stjepana-loze-hrvoju-klasicui-damiru-pilicu-sramota-kakvi-pojedinci-predaju-na-filozofskom-fakultetui-deformiraju-nove-generacije-hrvatskih-povjesnicara.

„Održan History Fest”. Portal Historiografija.hr (Zagreb), 7. 6. 2019. Pristup ostvaren 7. 6. 2019. http://www.historiografija.hr/?p=15186.

PETRANOVIĆ, Branko. Revolucija i kontrarevolucija u Jugoslaviji (19411945). Beograd: „Rad”, 1983.

PETRANOVIĆ, Branko. Srbija u Drugom svetskom ratu 1939-1945. Beograd: VINC, 1992.

PRPIĆ, Ivan. „Napomena” i „Suvremenost Bernsteinova revizionizma”. U: Eduard Bernstein, Ivanoe Bonomi, Jean Jaurès, Saverio Merlino, Georges Sorel, Peter von Struve, Revizionizam. Zagreb: Globus, 1981, VII-XLI.

RADELIĆ, Zdenko. Hrvatska u Jugoslaviji 1945. - 1991. Od zajedništva do razlaza. Zagreb: Školska knjiga; Hrvatski institut za povijest, 2006.

„Revizionizam”. U: Politička enciklopedija. Beograd: Savremena administracija, 1975, 910.

ROGIĆ, Ivan. Tehnika i samostalnost. Okvir za sliku treće hrvatske modernizacije. Zagreb: Hrvatska sveučilišna naklada, 2000.

RUDAN, Vedrana. „Pionir Raspudić, Nino Raspudić”. Portal rudan.info, 30. 6. 2017. Pristup ostvaren 2. 2. 2019. http://www.rudan.info/pionir-raspudic-nino-raspudic/.

STANKOVIĆ, Đorđe; DIMIĆ, Ljubodrag. Istoriografija pod nadzorom. Prilozi istoriji istoriografije. Beograd: Službeni list SRJ, 1996.

ŠONJE, Jure. „Goldstein, Slavko”. U: Hrvatski biografski leksikon, sv. 5. Zagreb: Leksikografski zavod „Miroslav Krleža”, 2002, 25.

ŠTAVLJANIN, Dragan. „Ivo Goldstein: Istinu o Jasenovcu zna svatko tko želi”. Radio Slobodna Evropa (Prag), 30. 4. 2018. Pristup ostvaren 10. 6. 2019. https://www.slobodnaevropa.org/a/ivo-goldstein-jasenovac-logor-/29198835. html.

ŠUVAR, Stipe. „Historija revolucije tiče se nas svih (Nekoliko uvodnih napomena za raspravu)". U: Historija i suvremenost. Idejne kontroverze. Zagreb: Centar CK SKH za idejno-teorijski rad „Vladimir Bakarić”; ČGP „Delo”; OOUR Globus, 1984, 9-15. 
TERZIĆ, Velimir. Slom Kraljevine Jugoslavije 1941. Beograd: Narodna knjiga, 1982.

VUČETIĆ, Radina. „O jednom jubileju ili kako se (ne) sećamo Jugoslavije". Portal Historiografija.hr (Zagreb), 19. 5. 2018. Pristup ostvaren 14. 6. 2019. http://www.historiografija.hr/?p=9891.

VUKIĆ, Igor. Radni logor Jasenovac. Zagreb: Naklada Pavičić, 2018.

Z. K. / HINA. „Goldstein: Jasenovac je kompleksna priča i licitiranje brojem žrtava je nedopustivo". tportal.hr (Zagreb), 31. 5. 2019. Pristup ostvaren 7. 6. 2019. https://www.tportal.hr/biznis/clanak/goldstein-jasenovac-je-kompleksna-prica-i-licitiranje-brojem-zrtava-je-nedopustivo-20190531.

ŽERJAVIĆ, Vladimir. Opsesije i megalomanije oko Jasenovca i Bleiburga. Gubici stanovništva Jugoslavije u Drugom svjetskom ratu. Zagreb: Globus, 1992. 


\section{SUMMARY}

\section{Contemporary Croatian History and Troubles with Revisionism}

The term 'historical revisionism' appeared in Croatia at the beginning of the $21^{\text {st }}$ century. The term 'revisionism' in communist Yugoslavia fell exclusively within the sphere of Marxism and signified a standpoint that advocated abandonment of the dictatorship of the proletariat and an acceptance of the rules of parliamentary democratic struggle. The term 'historical revisionism' appeared in the Goldstein family circle in 2001. A key role in this was played by publisher, writer, and influential political activist Slavko Goldstein. The term was then systematically exploited by his son, the historian Ivo Goldstein, and is today very common among the left and far-left wing of Croatian society. In 2001, S. Goldstein claimed that revisionism in Croatia had appeared in 1989-90 as a historiographical retardation and socio-political anomaly. In contrast to Western countries, it was tolerated and encouraged by the country's new political leadership from 1990 on, and partially adopted into its political programme. Its general characteristic and basic starting point is - fetishisation of the state and fetishisation of the Croatian state-building idea!' With strong media support and political backing, S. Goldstein managed to turn something nonsensical into a question of 'vital importance.' Calling someone out for revisionism in science, and therefore historiography, is absurd, because 'any statement becomes outdated and eventually needs revising'. Calling out for historical revisionism therefore aims to thwart any attempt to question the image of World War II that was created in communist Yugoslavia before 1990, and dissuade potential researchers. The question of whether scholars are 'revisers' or 'revisionists' is therefore a waste of time.

Key words: historiography; revisionism; Slavko Goldstein; Franjo Tuđman; Independent State of Croatia; Socialist Republic of Croatia; Croatia 